\title{
Apoptosis of CD4 $4^{+}$D25 $5^{\text {high }}$ T Cells in Type 1 Diabetes May Be Partially Mediated by IL-2 Deprivation
}

\section{Parthav Jailwala ${ }^{19}$, Jill Waukau ${ }^{19}$, Sanja Glisic ${ }^{1}$, Srikanta Jana ${ }^{1}$, Sarah Ehlenbach ${ }^{1}$, Martin Hessner ${ }^{1}$, Ramin Alemzadeh ${ }^{2}$, Shigemi Matsuyama ${ }^{3}$, Purushottam Laud ${ }^{4}$, Xujing Wang ${ }^{5}$, Soumitra Ghosh ${ }^{1 *}$}

1 The Max McGee National Research Center for Juvenile Diabetes and The Human and Molecular Genetics Center, Department of Pediatrics at the Medical College of Wisconsin and the Children's Research Institute of the Children's Hospital of Wisconsin, Milwaukee, Wisconsin, United States of America, $\mathbf{2}$ Children's Hospital of Wisconsin Diabetes Center, Pediatric Endocrinology and Metabolism, Medical College of Wisconsin, Milwaukee, Wisconsin, United States of America, 3 Department of Pharmacology, Case Western Reserve University, Cleveland, Ohio, United States of America, 4 Division of Biostatistics, Medical College of Wisconsin, Milwaukee, Wisconsin, United States of America, $\mathbf{5}$ Department of Physics \& the Comprehensive Diabetes Center, University of Alabama at Birmingham, Birmingham, Alabama, United States of America

\begin{abstract}
Background: Type 1 diabetes (T1D) is a T-cell mediated autoimmune disease targeting the insulin-producing pancreatic $\beta$ cells. Naturally occurring FOXP3 ${ }^{+} \mathrm{CD} 4^{+} \mathrm{CD} 25^{\text {high }}$ regulatory $\mathrm{T}$ cells $\left(\mathrm{T}_{\text {regs }}\right.$ ) play an important role in dominant tolerance, suppressing autoreactive CD4 ${ }^{+}$effector T cell activity. Previously, in both recent-onset T1D patients and $\beta$ cell antibodypositive at-risk individuals, we observed increased apoptosis and decreased function of polyclonal $\mathrm{T}_{\text {regs }}$ in the periphery. Our objective here was to elucidate the genes and signaling pathways triggering apoptosis in $T_{\text {regs }}$ from T1D subjects.

Principal Findings: Gene expression profiles of unstimulated $T_{\text {regs }}$ from recent-onset T1D $(n=12)$ and healthy control subjects $(n=15)$ were generated. Statistical analysis was performed using a Bayesian approach that is highly efficient in determining differentially expressed genes with low number of replicate samples in each of the two phenotypic groups. Microarray analysis showed that several cytokine/chemokine receptor genes, HLA genes, GIMAP family genes and cell adhesion genes were downregulated in $T_{\text {regs }}$ from T1D subjects, relative to control subjects. Several downstream target genes of the AKT and p53 pathways were also upregulated in T1D subjects, relative to controls. Further, expression signatures and increased apoptosis in $T_{\text {regs }}$ from T1D subjects partially mirrored the response of healthy $T_{\text {regs }}$ under conditions of IL-2 deprivation. CD4 ${ }^{+}$effector T-cells from T1D subjects showed a marked reduction in IL-2 secretion. This could indicate that prior to and during the onset of disease, $T_{\text {regs }}$ in T1D may be caught up in a relatively deficient cytokine milieu.
\end{abstract}

Conclusions: In summary, expression signatures in $\mathrm{T}_{\text {regs }}$ from T1D subjects reflect a cellular response that leads to increased sensitivity to apoptosis, partially due to cytokine deprivation. Further characterization of these signaling cascades should enable the detection of genes that can be targeted for restoring $T_{\text {reg }}$ function in subjects predisposed to T1D.

Citation: Jailwala P, Waukau J, Glisic S, Jana S, Ehlenbach S, et al. (2009) Apoptosis of CD4 ${ }^{+}$CD25 high $T$ Cells in Type 1 Diabetes May Be Partially Mediated by IL-2 Deprivation. PLoS ONE 4(8): e6527. doi:10.1371/journal.pone.0006527

Editor: Patrick Tan, Duke-NUS Graduate Medical School, Singapore

Received April 21, 2009; Accepted July 2, 2009; Published August 5, 2009

Copyright: (c) 2009 Jailwala et al. This is an open-access article distributed under the terms of the Creative Commons Attribution License, which permits unrestricted use, distribution, and reproduction in any medium, provided the original author and source are credited.

Funding: This work was supported by General Clinical Research Center of The Medical College of Wisconsin, Grant M01-RR00058 and the McGee funds from the Children's Research Institute (\#2750.615). The funders had no role in study design, data collection and analysis, decision to publish, or preparation of the manuscript.

Competing Interests: The authors have declared that no competing interests exist.

*E-mail: sghosh@mcw.edu

9 These authors contributed equally to this work.

\section{Introduction}

Type 1 diabetes (T1D) results from the T-cell-mediated autoimmune destruction of the insulin-producing pancreatic islet $\beta$ cells. This breakdown of immunological self-tolerance results in autoreactivity to islet self-antigens, and requires genetic susceptibility as well as environmental factors. Both the numerical and functional balance between killer (e.g., $\mathrm{CD}^{+}$and $\mathrm{CD}^{+}$effectors) and regulatory $\mathrm{T}$-cells in the pancreatic infiltrate determines the extent of $\beta$ cell destruction [1]. Although islet infiltrates have shown the presence of cytotoxic effector T-cells and pro-inflammatory cytokines [2], there is still a major void in our understanding of how these effector cells escape peripheral regulation.
Among the regulatory $\mathrm{T}$-cells that actively suppress effector $\mathrm{T}$ cells, the FOXP $3^{+} \mathrm{CD} 4^{+} \mathrm{CD} 25^{\text {high }} \mathrm{T}$-cells $\left(\mathrm{T}_{\text {regs }}\right)$ represent one of the best characterized sub-populations. There is accumulating evidence of a deficiency in either the frequency or function of $T_{\text {regs }}$ in various human autoimmune diseases [3], as well as in the pathogenesis of T1D [4-7]. During the period right after disease onset, which lasts several months after clinical diagnosis, most T1D patients have some residual $\beta$-cell function $[8,9]$. Our group is interested to study immune responses in the periphery related to $\beta$-cell destruction and progression of disease during this recentonset period. We previously reported evidence for increased apoptosis of $\mathrm{T}_{\text {regs }}$ in recent-onset T1D subjects (all diagnosed within 1 year, henceforth referred to as "T1D subjects") and in 
subjects at-risk for T1D [10]. This increase in $\mathrm{T}_{\text {reg }}$ apoptosis was found to correlate with a decline in suppressive potential of these cells. The fact that both hyperglycemic T1D subjects and normoglycemic at-risk subjects showed this phenomenon suggests that $\mathrm{T}_{\text {reg }}$ apoptosis is more a precursor to, rather than a consequence of diabetes. Although $\mathrm{T}_{\text {reg }}$ apoptosis is likely to be one of the peripheral imbalances in $\mathrm{T} 1 \mathrm{D}$, there is very little known about the pathways and genes that make $\mathrm{T}_{\text {regs }}$ sensitive to apoptosis during the period right after the onset of disease.

Several groups have studied expression profiles for various subsets of T-cells in both humans and mice, aimed at objectives ranging from differentiating regulatory $\mathrm{T}$-cells from effector $\mathrm{T}$ cells $[11,12]$ to understanding the FOXP3-dependent regulatory phenotype [13,14], or studying how these cells respond to cytokine stimulation [15-17]. These studies have contributed significantly to a better understanding of the mechanisms underlying $\mathrm{T}_{\text {reg }}$ mediated tolerance under physiological conditions. There are also studies which have investigated $\mathrm{T}_{\text {reg }}$ expression under diseased conditions in mouse models for T1D $[18,19]$. Recent studies have explored the expression signatures in peripheral blood mononuclear cells (PBMC) and in CD4 ${ }^{+} \mathrm{T}$ cells of human T1D and T2D subjects $[20,21]$. However, expression profiles in unfractionated PBMC (or in the $\mathrm{CD} 4^{+} \mathrm{T}$ cell subset) comprising a heterogeneous cell population are difficult to correlate with expression changes that should occur specifically in apoptosis-sensitive $T_{\text {regs }}$ at the onset of T1D.

In this study, we investigated the expression signature that shapes the transcriptional program within functionally deficient $\mathrm{T}_{\text {regs }}$ from recent-onset T1D. Expression profiles of unstimulated $\mathrm{T}_{\text {regs }}$ from T1D subjects reveal a cellular response that could make the cells sensitive to apoptosis, partially due to deprivation of cytokines. This global picture of pathway-specific expression signatures is a step further into dissecting $\mathrm{T}_{\text {reg }}$ dysfunction in the pathogenesis of T1D.

\section{Results}

\section{$T_{\text {regs }}$ from T1D subjects exhibit reduced suppressive capacity and increased apoptosis}

We first investigated a possible functional deficiency in $T_{\text {regs }}$ from T1D subjects, using a suppression assay. In a pilot suppression assay, $\mathrm{T}_{\text {regs }}$ from healthy control subjects were cocultured with $\mathrm{CD} 4^{+} \mathrm{CD} 25^{-}$effector T-cells (CD25 $\left.{ }^{-} \mathrm{T}_{\text {effs }}\right)$ at varying titrations of the $\mathrm{T}_{\text {reg }}: \mathrm{CD} 25^{-} \mathrm{T}_{\text {eff }}$ ratio (from 1:2 to $1: 32$ ) and the suppressive capacity of $\mathrm{T}_{\text {regs }}$ was measured using the formula described in the methods. Varying the CD25 ${ }^{-} \mathrm{T}_{\text {eff }}$ numbers resulted in minor changes in suppression (Figure 1A). Hence, we chose to carry out suppression assays at a 1:10 $\left(\mathrm{T}_{\text {reg: }}\right.$ : CD $25^{-} \mathrm{T}_{\text {eff }}$ ) ratio for the rest of the study. $\mathrm{T}_{\text {regs }}$ from T1D subjects $(\mathrm{n}=15)$ showed a significant reduction in suppressive capacity compared to control subjects $(\mathrm{n}=17)$ (Mann-Whitney $\mathrm{p}<0.0007$ ) (Figure 1B). The raw CPM counts in single and co-culture were comparable within the two phenotypic groups and the low background counts confirmed that there was no media contamination (Figure $\mathrm{S} 1$ ). We further checked if ongoing spontaneous apoptosis could also be detected in $\mathrm{T}_{\text {regs }}$ from $\mathrm{T} 1 \mathrm{D}$ subjects that showed reduced function. We observed that $T_{\text {regs }}$ from T1D subjects had significantly elevated levels of apoptosis, compared to control subjects (Mann-Whitney $\mathrm{p}<0.0001$ ) (Figure 1G), but there was no difference in apoptosis of CD25 ${ }^{-} \mathrm{T}_{\text {effs }}$ across the two phenotypes (Figure 1D). Also, while there was no difference in apoptosis across $\mathrm{T}_{\text {regs }}$ and CD25 ${ }^{-} \mathrm{T}_{\text {effs }}$ from the same control subjects, $\mathrm{T}_{\text {regs }}$ displayed higher apoptosis levels compared to CD25 ${ }^{-} \mathrm{T}_{\text {effs }}$ cells from the same T1D subjects. A representative flow cytometry plot for isolation of apoptotic cells is shown in Figure S2.

These results strengthened the trends reported earlier by our group in T1D subjects and at-risk non-diabetic individuals [10]. Furthermore, they suggest that in T1D subjects as well as in normoglycemic at-risk subjects, $\mathrm{T}_{\text {regs }}$ undergo spontaneous apoptosis in the periphery, which could result in a subsequent loss of suppressive potential. Increased apoptosis and decreased suppression of $\mathrm{T}_{\text {regs }}$ observed in both recent-onset T1D subjects and in atrisk individuals who have not yet been clinically diagnosed with disease, indicates that these $\mathrm{T}_{\text {reg }}$ defects are more a cause than an effect of the disease.

Several reports have demonstrated that IL-2 is an important signal for the development, function and homeostasis of natural $\mathrm{T}_{\text {regs }}$ in-vivo [22-29]. Tang et al.[30] reported that in the NOD mice (which spontaneously develops diabetes), disease progression was associated with a loss of $\mathrm{T}_{\text {reg }}$ : $\mathrm{CD} 4^{+} \mathrm{T}_{\text {eff }}$ balance in the islets with concomitant reduction of CD25 and BCL2 expression on intra-islet $\mathrm{T}_{\text {reg }}$ cells. Addition of IL-2 promoted $\mathrm{T}_{\text {reg }}$ cell survival and protected NOD mice from diabetes. Further, in the NOD mouse, Yamanouchi et al. have shown that IL-2 gene variation impairs $\mathrm{T}_{\text {reg }}$ function and influences diabetes susceptibility. They have also shown that the amount of IL-2 produced by autoreactive CD8+ $\mathrm{T}$ cells in response to antigen seems to control the size of the lymph node $\mathrm{T}_{\text {reg }}$ pool [31]. Based on this collective evidence of the role of IL-2 in $\mathrm{T}_{\text {reg }}$ function, we hypothesized that reduced IL2 could be partially responsible for the increased apoptosis and reduced function of $\mathrm{T}_{\text {regs }}$ from human T1D subjects. Further evidence in support of this hypothesis is presented in the following sections.

\section{Increased apoptosis in $\mathrm{T}_{\text {regs }}$ from T1D subjects is reproducible in healthy $T_{\text {regs, }}$ under conditions of IL-2 deprivation}

First, we tested if increased apoptosis could be reproducible in healthy $\mathrm{T}_{\text {regs }}$, under conditions of IL-2 and IL-4 deprivation. It can be argued that it is more useful to establish the link between cytokine deprivation and apoptosis directly in $\mathrm{T}_{\text {regs }}$ from T1D subjects. However, functionally deficient $\mathrm{T}_{\text {regs }}$ from T1D subjects are likely to undergo irreversible apoptosis/necrosis in response to IL-2 deprivation, making this sort of analysis uninformative. Apoptosis was measured in $\mathrm{T}_{\text {regs }}$ and in CD25 $5^{-} \mathrm{T}_{\text {eff }}$ cells from control subjects, at 3 days and 5 days after IL-2, IL-4 and IL-2+IL4 withdrawal. Results show that there was increased apoptosis in $\mathrm{T}_{\text {regs }}$, but not in CD25 ${ }^{-} \mathrm{T}_{\text {effs }}$ in response to IL-2 and IL-4 deprivation (Figure 2). Further, within $\mathrm{T}_{\text {regs }}$, withdrawal of IL-2 leads to a strong apoptosis response, compared to withdrawal of IL-4. Also, at 5 days of co-culture, the effect of IL-2-deprivation on apoptosis was more pronounced. Remarkably, this pattern of elevated apoptosis in healthy $\mathrm{T}_{\text {regs }}$ under conditions of IL-2 deprivation replicated that observed in $\mathrm{T}_{\text {regs }}$ from T1D subjects when compared to control subjects.

\section{Gene expression signatures in $\mathrm{T}_{\text {regs }}$ from T1D subjects reveal modulation of several apoptosis genes, possibly due to cytokine deprivation}

We then proceeded to profile gene expression changes that could discriminate functionally deficient and apoptosis-sensitive $\mathrm{T}_{\text {regs }}$ from their healthy counterparts. Out of $16 \mathrm{~T} 1 \mathrm{D}$ and 25 control subjects assayed for $\mathrm{T}_{\text {reg }}$ apoptosis and suppression, 12 T1D and 15 control subjects yielded sufficient RNA for expression profiling. $\mathrm{T}_{\text {regs }}$ were freshly isolated from PBMC and amplified RNA was hybridized to the microarray as described in the 
A
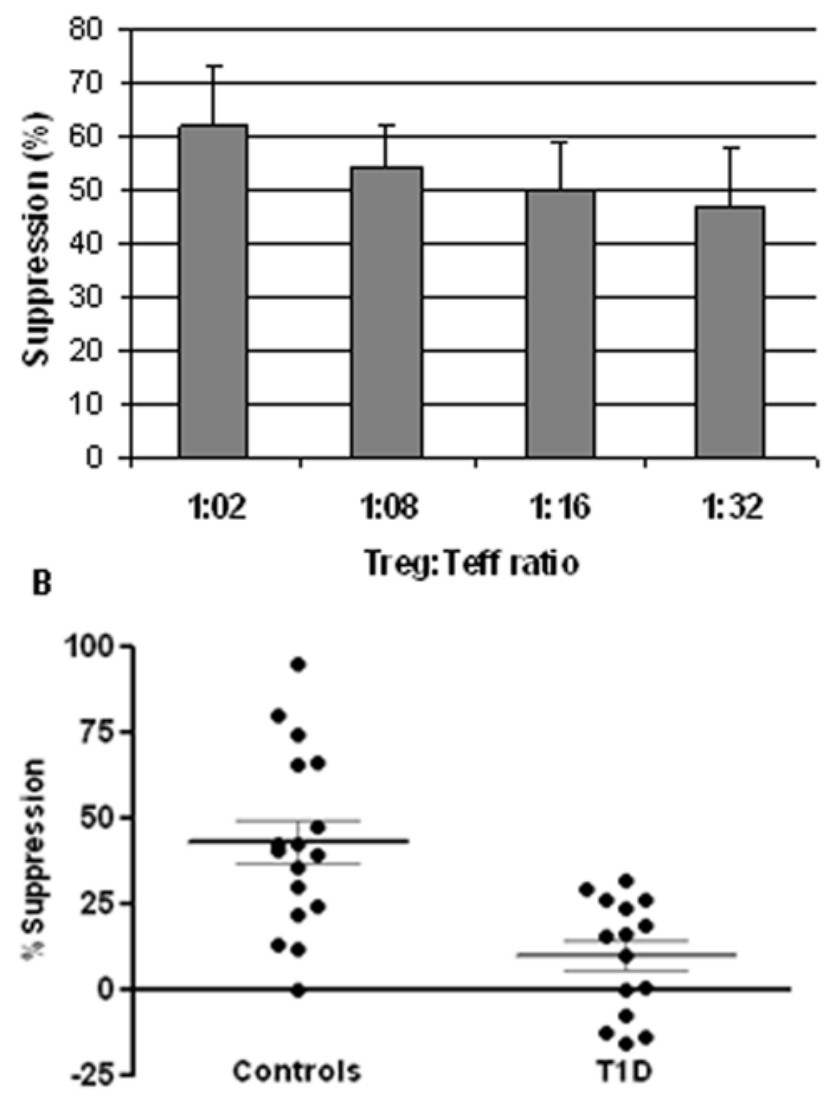

C

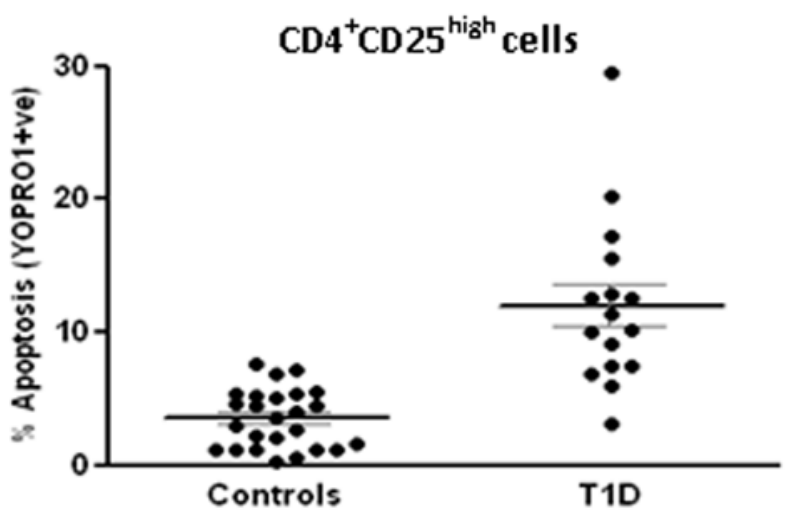

D

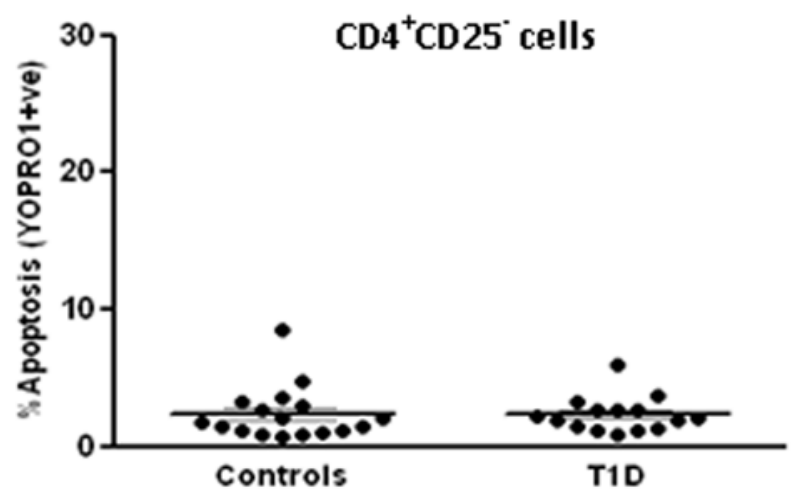

Figure 1. In T1D subjects, $\mathrm{T}_{\text {regs }}$ isolated from $\mathrm{CD4}^{+} \mathrm{T}$ cells have reduced function and increased apoptosis. Standard in vitro suppression assay included 25,000 responder $C D 4^{+} \mathrm{CD}_{2} 5^{-} \mathrm{T}$ cells that were set up as single culture as well as with $\mathrm{CD} 4^{+} \mathrm{CD} 25^{\text {high }} \mathrm{T}$ cells in coculture, both with added 25,000 of irradiated PBMCs (as antigenpresenting cells) which were stimulated with aCD3-coated beads $(1 \mu \mathrm{g} /$ $\mathrm{ml}$ ) for 5 days. Ratio of responder and $\mathrm{CD} 4^{+} \mathrm{CD} 25^{\text {high }} \mathrm{T}$ cells was varied. Suppressors were seeded with APC in separate wells to measure their own proliferation in respond to the same stimulation. Bars are mean \pm SEM of three independent observations. (B) Suppression potential of isolated $\mathrm{CD} 4^{+} \mathrm{CD} 25^{\text {high }} \mathrm{T}$-cells measured by an in vitro proliferation assay in T1D $(n=17)$ and control $(n=15)$ subjects. A standardized suppression assay was performed with $2.5 \times 10^{4}$ $\mathrm{CD}^{+} \mathrm{CD} 25^{-}$effector T-cells (with $2.5 \times 10^{4}$ irradiated PBMC $-5000 \mathrm{rad}$ ) in co-culture with $\mathrm{CD} 4^{+} \mathrm{CD} 25^{\text {high }} \mathrm{T}$-cells at a 1:10 ratio $\left(\mathrm{CD} 4^{+} \mathrm{CD} 25^{\text {high }}\right.$ : $\left.\mathrm{CD} 4^{+} \mathrm{CD} 25^{-}\right)$, stimulated with aCD3 coated beads $(1 \mathrm{ug} / \mathrm{ml}, 3$ beads/per cell). Apoptosis results following YOPRO-1/7AAD staining for (C) CD4 $4^{+} C D 25^{\text {high }}$ (T1D: $n=16$, controls: $n=25$ ) and (D) $C D 4^{+} C D 25^{-}$T-cells (T1D: $n=15$, controls: $n=17$ ) are both presented as $\%$ apoptotic (YOPRO1+ve) amongst live cells (7AAD-ve). doi:10.1371/journal.pone.0006527.g001

methods. Bayesian hierarchical analysis identified 1205 differentially regulated genes $(\mid z$-score $\mid>20)$ across the two phenotypic groups. Of these, 947 genes were upregulated in T1D subjects and 248 genes were downregulated in T1D subjects, compared to control subjects. $\mathrm{T}_{\text {regs }}$ used in this expression study were not subjected to any stimulation, as these cells are known to be susceptible to activation-induced cell death, whereby any resulting differences in apoptosis-related gene expression could be nullified $[32,33]$. Hence the relatively modest magnitude of expression changes $( \pm 2.5$-fold or less) was expected in this dataset. It is now known that for minimal changes in gene expression, instead of a gene-by-gene approach [34], detecting predefined co-regulated gene sets for association with disease phenotypes has more power of discovering biological themes within functionally related sets of genes. We used EASE, a pathway enrichment tool, to find the biological pathways perturbed in each phenotype [35]. Within EASE, three functional categorization systems, viz. Organismal role, GO Molecular function and Interpro were probed individually for pathway terms associated with each of the two phenotypes. To rank pathway terms by over-representation, we used the significance cutoffs on the EASE score (see the methods section for details on the EASE score). The 5 most significantly enriched pathway terms and associated EASE scores under each of the three categorization systems are shown in Table 1. For the gene list downregulated in T1D subjects, there was a nearsignificant enrichment (EASE score $<0.06$ ) of terms related to cell migration/motility, cytokine binding, $M H C$ class II receptor activity, chemokine receptor activity, chemokine receptor \& MHC Class II, alpha chain.

Next, we extracted the identities and annotations of the genes that featured in the enrichment results, as well as other differentially expressed genes that are members of these functional clusters. These differentially regulated genes are shown in Figure 3, along-with their functional grouping and associated fold changes. Our primary observation was that several apoptosis-related genes were differentially regulated in $\mathrm{T}_{\text {regs }}$ from T1D subjects, compared to control subjects (all significant at $\mid \mathrm{z}$-score $\mid>20$ ). BCL2, an antiapoptotic gene which represses the caspase cascade and is known to make $\mathrm{CD} 4^{+} \mathrm{T}$ cells sensitive to apoptosis under conditions of serum starvation [36], was downregulated in T1D subjects. Cytochrome c (CYCS), whose release from the mitochondria is normally blocked by $B C L 2$, as well as FAS and BCL10- two major caspase activators, were also upregulated in $T_{\text {regs }}$ from T1D subjects. Further, genes related to stress response and known to be 
A

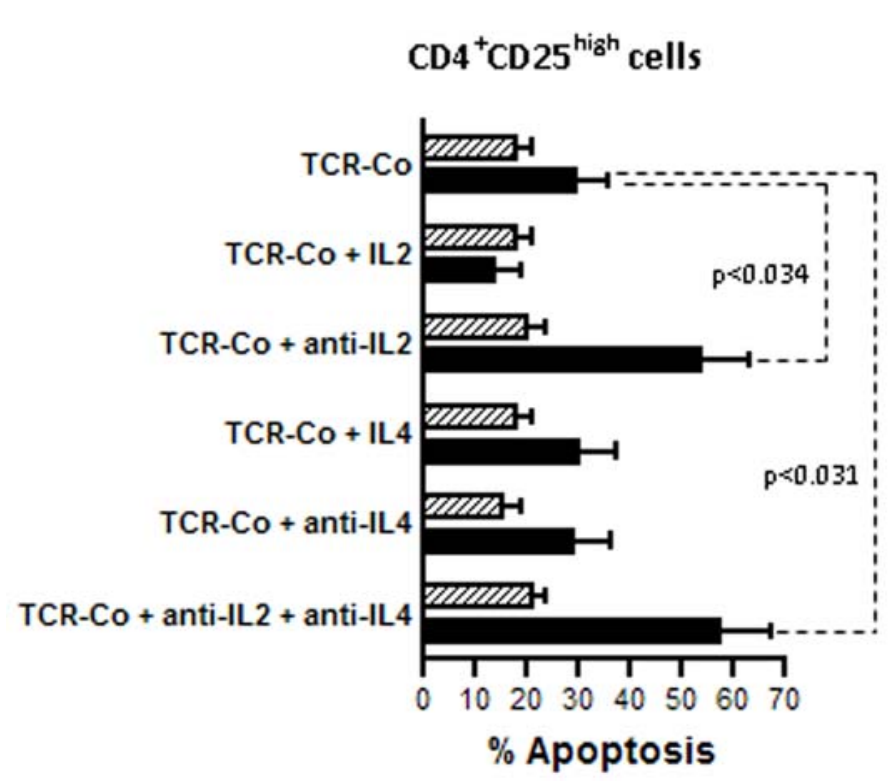

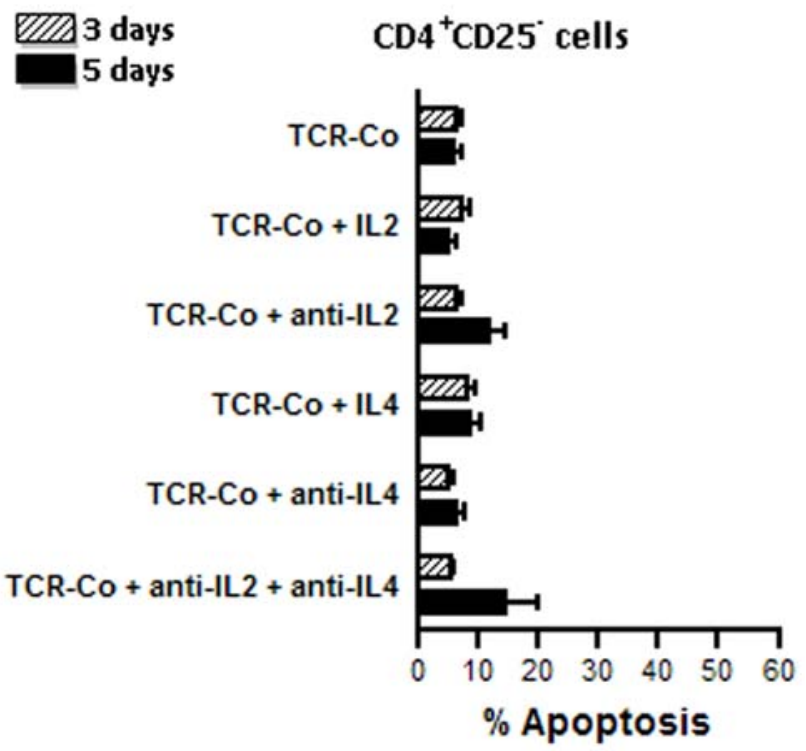

Figure 2. Under conditions of IL-2 and IL-4 withdrawal, apoptosis in healthy $T_{\text {regs }}$ mimics the increased apoptosis in $T_{\text {regs }}$ from T1D subjects. Apoptosis was measured in (A) healthy $\mathrm{T}_{\text {regs }}$ and (B) $\mathrm{CD} 4^{+} \mathrm{CD} 25^{-}$effector T-cells at 3 days and 5 days, in response to IL-2 and IL-4 deprivation as described in the methods. Overall, in response to IL-2- and IL-4- deprivation, $\mathrm{T}_{\text {regs }}$ show more apoptosis compared to effector T-cells. Further, within $\mathrm{T}_{\text {regs, }}$ withdrawal of IL-2 leads to a strong apoptosis response, compared to withdrawal of IL-4. Also, this difference in apoptosis was more prominent after 5 days of IL-2 withdrawal. The bars depict the mean \pm SEM of six independent observations.

doi:10.1371/journal.pone.0006527.g002

triggered by lack of survival factors [37], were upregulated in $\mathrm{T}_{\text {regs }}$ from T1D subjects. The transcription factor FOXO3A as well as some its key pro-apoptotic transcriptional targets $(G A D D 45 A$,
GADD45B, SESN1, CDKN1B, CITED2 and TNFRSF10B) were upregulated in $\mathrm{T}_{\text {regs }}$ from T1D subjects. Pro-apoptotic genes in the p53 signaling pathway (STK17A, STK17B, GADD45A, GADD45B,

Table 1. Pathway enrichment analysis using EASE.

\begin{tabular}{|c|c|c|c|}
\hline & EASE score & Gene Category & EASE score \\
\hline Organismal role & & Organismal role & \\
\hline General cellular role & $3.73 \mathrm{E}-05 *$ & Anti-pathogen response & $2.92 \mathrm{E}-02$ \\
\hline Angiogenesis & 8.77E-02 & Cell migration/motility & $5.83 \mathrm{E}-02$ \\
\hline Cell death/Apoptosis & $1.18 \mathrm{E}-01$ & Pathogenic Invasion & $6.68 \mathrm{E}-02$ \\
\hline Anti-pathogen response & $1.40 \mathrm{E}-01$ & Neuronal development & $3.01 \mathrm{E}-01$ \\
\hline Control of Cell Proliferation & 5.47E-01 & Other development & $6.35 \mathrm{E}-01$ \\
\hline GO Molecular Function & & GO Molecular Function & \\
\hline Nucleic acid binding & $9.92 \mathrm{E}-08 *$ & Cytokine binding & $9.00 \mathrm{E}-05$ \\
\hline Hydrogen ion transporter activity & $1.16 \mathrm{E}-07$ * & MHC class II receptor activity & $1.28 \mathrm{E}-04$ \\
\hline Monovalent inorganic cation transporter activity & $3.70 \mathrm{E}-07$ * & Transmembrane receptor activity & $1.34 \mathrm{E}-04$ \\
\hline RNA binding & $2.13 \mathrm{E}-06$ * & $\mathrm{C}-\mathrm{C}$ chemokine binding & $2.46 \mathrm{E}-04$ \\
\hline Cation transporter activity & $3.02 \mathrm{E}-05 *$ & C-C chemokine receptor activity & $2.46 \mathrm{E}-04$ \\
\hline Interpro & & Interpro & \\
\hline Helicase C-terminal domain & $1.08 \mathrm{E}-02 *$ & Chemokine receptor & $5.93 \mathrm{E}-03$ \\
\hline DEAD/DEAH box helicase & $1.08 \mathrm{E}-02 *$ & Immunoglobulin C-type & 2.94E-02 \\
\hline ATP-dependent helicase, DEAD-box & $1.80 \mathrm{E}-02 *$ & MHC Class II, alpha chain & $3.21 \mathrm{E}-02$ \\
\hline Proline rich extensin & $3.52 \mathrm{E}-02$ * & Ras GTPase-activating proteins & 7.33E-02 \\
\hline Spectrin repeat & $6.44 \mathrm{E}-02$ & Immunoglobulin and MHC domain & 1.12E-01 \\
\hline
\end{tabular}

Left panel): Top 5 terms amongst the 948 genes upregulated in T1D (FDR $<5 \%$ ), in each of the three functional classification systems. (Right panel): Top 5 terms amongst the 257 genes downregulated in T1D (FDR $<5 \%$ ), in each of the different functional classification systems. Terms marked with an asterisk (*) are statistically significant at EASE score $<0.05$

doi:10.1371/journal.pone.0006527.t001 
SESN3, DYRK2 and BIM) were upregulated in $\mathrm{T}_{\text {regs }}$ from T1D subjects. Finally, several members of the GIMAP gene family (implicated with T1D in the rat [38-40]), HLA genes as well as cytokine/chemokine receptors were downregulated in $\mathrm{T}_{\text {regs }}$ from T1D subjects. In summary, the downregulation of AKT1 and the concomitant upregulation of FOXO3A/p53 targets in $\mathrm{T}_{\text {regs }}$ from T1D subjects mirrored a cytokine deprivation mediated stress response that could lead to AKT pathway mediated cell cycle arrest.

For confirmation of array results by quantitative RT-PCR, we restricted the selection of apoptosis-related and HLA Class I/Class II genes to only those that were reported as differentially expressed using both SAM $($ FDR $<10 \%)$ and BGX $(\mid z$-score $\mid>20)$ analyses. RT-PCR results (Figure 4) confirm the upregulation of PTEN, $F A S$, as well as several pro-apoptotic transcriptional targets of FOXO3A in $\mathrm{T}_{\text {regs }}$ from T1D subjects (GADD45A, GADD45B, SESN1, PUMA and TNFRSF10B). Downregulation of CCND2, a negative target of $F O X O 3 A$, was also confirmed. Trends in the expression of HLA Class I (HLA-A,HLA-C,HLA-E) and HLA Class II genes (HLA-DQA1, HLA-DQB1, HLA-DRB1, HLA-DRA1) were similar to those observed on the array. In agreement with the array results, GIMAP5 was also found to be downregulated by RTPCR. Thus, RT-PCR results confirm several array results, and establish the expression changes in the AKT pathway that make $\mathrm{T}_{\text {regs }}$ from T1D subjects sensitive to apoptosis.

For reproducing expression signatures seen in $T_{\text {regs }}$ from T1D subjects, we selected 32 key genes from the various functional clusters discussed so far (15 apoptosis-related genes, 11 cytokine \& chemokine receptors and 6 GIMAP genes), and checked their expression trends in healthy $\mathrm{T}_{\text {regs }}$, under conditions of IL-2 deprivation. As array results suggested early gene expression changes leading to apoptosis, we checked RNA expression at 12 hours, 24 hours and 3 days after IL-2 withdrawal. Results show that expression trends in TCR-Co $(\alpha \mathrm{CD} 3+\alpha \mathrm{CD} 28)$ stimulated healthy $\mathrm{T}_{\text {regs }}$ under IL-2 withdrawal were in agreement with expression trends in $\mathrm{T}_{\text {regs }}$ from T1D subjects, for 19 of the 32 assayed genes (Figure 5). Expression trends in key apoptosis genes along the AKT/p53 signaling axis (upregulation of transcriptional targets of FOXO3A: TNFRSF10B, GADD45A, GADD45B and FAS) and cytokine/chemokine receptors (downregulation of ILIRI, CCR2, CCR6, CD58 and CXCR3) mimic those observed in $\mathrm{T}_{\text {regs }}$ from T1D subjects, at one or more time-points. Further, in the gene-expression results, important cytokine-responsive lymphocyte activation markers: interleukin-2 receptor alpha (IL2RA), chemokine (C-C motif) receptor 5 (CCR5) and human leukocyte antigen, class II, DR alpha 1 (HLA-DRA1) were downregulated in $\mathrm{T}_{\text {regs }}$
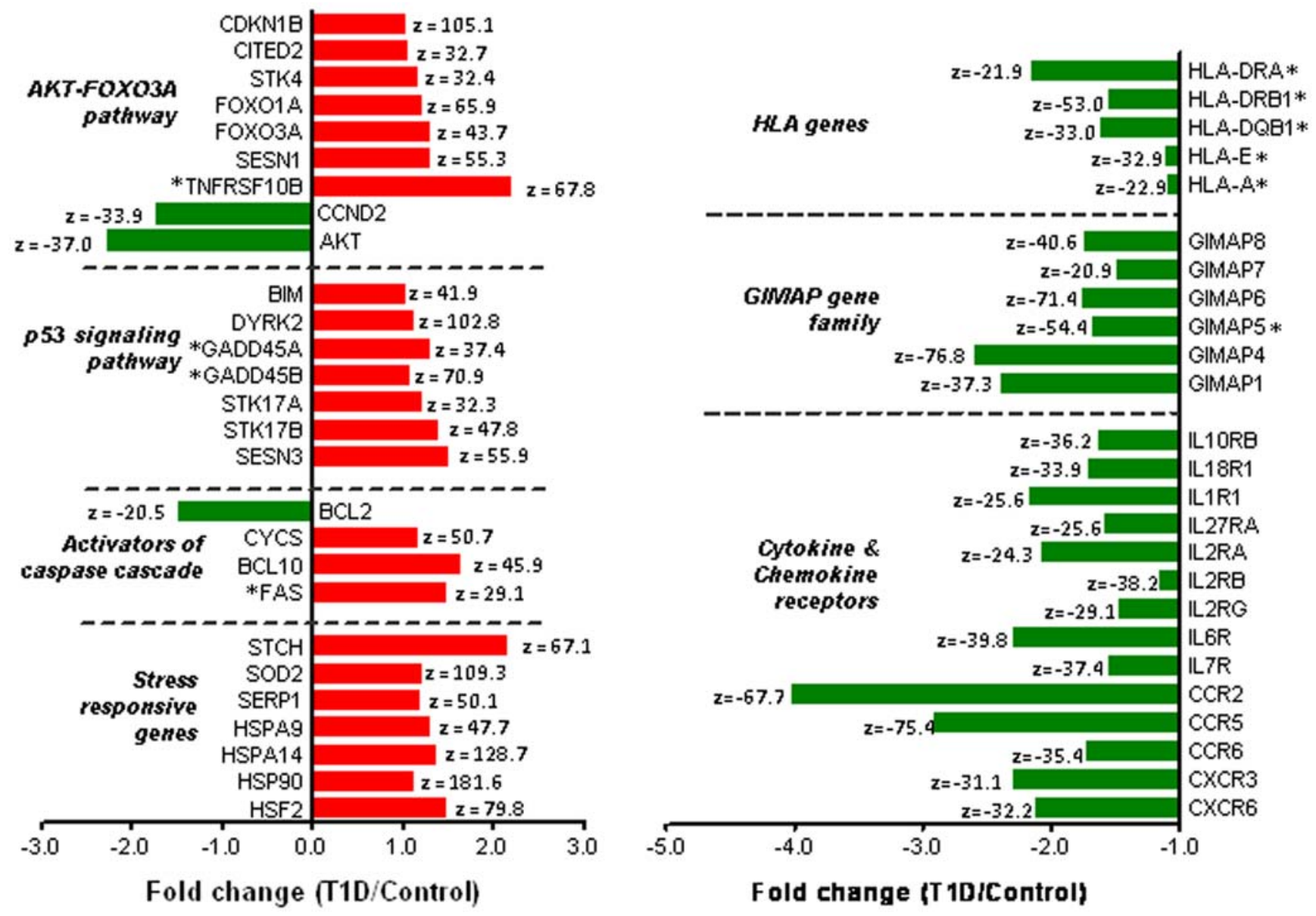

Figure 3. Expression trends of differentially regulated apoptosis genes on the array. This panel of genes shows the identity, functional grouping and the fold change of genes differentially regulated across T1D and control subjects $(|z-s c o r e|>20)$. The red bars represent genes that are upregulated in T1D subjects compared to controls and the green bars represent genes that are downregulated in T1D subjects compared to controls. The fold changes are as reported by BGX analysis. The gene symbols with an asterisk $\left(^{*}\right)$ represent genes whose expression was confirmed on the microarray as well as by RT-PCR.

doi:10.1371/journal.pone.0006527.g003 

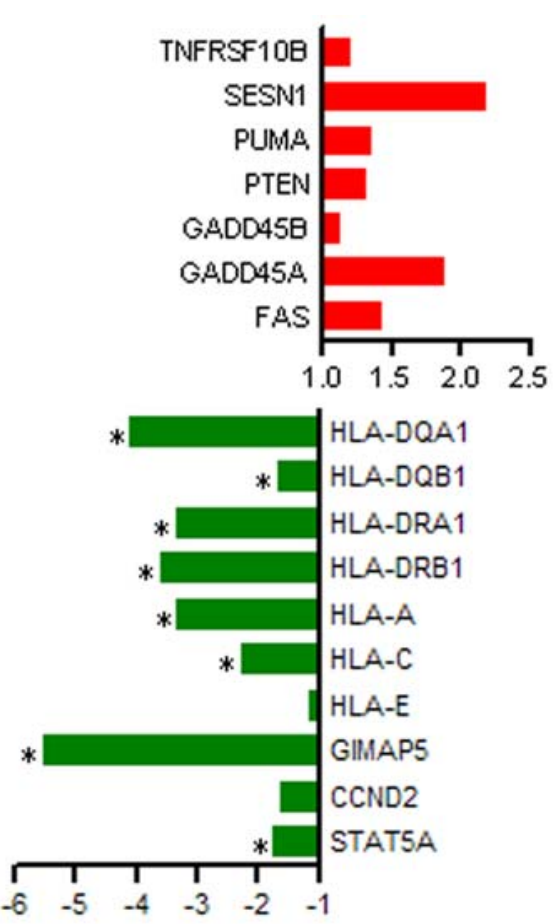

Fold change (T1D/Controls)

Figure 4. Confirmation of array results by RT-PCR. Expression results for several genes in the AKT pathway and HLA genes were confirmed by RT-PCR. For genes in the AKT pathway, the expression value is a ratio of the average expression across T1D subjects $(n=5)$ to the average expression across control subjects $(n=5)$. For HLA Class II genes, the expression value is a ratio of the average expression across T1D subjects $(n=6)$ to the average across controls subjects $(n=8)$. For HLA Class I genes, the expression value is a ratio of the average across T1D subjects $(n=10)$ to the average across control subjects $(n=10)$. Genes for which the expression ratios were statistically significant (Mann-Whitney $\mathrm{p} \leq 0.05$ ) are marked with an asterisk ${ }^{*}$ ). Subjects are not the same as those used for expression profiling. doi:10.1371/journal.pone.0006527.g004

from T1D subjects. It has been documented that these three activation-linked genes are positively regulated by IL-2 in various T-cell subsets $[41,42]$. In line with our hypothesis, withdrawal of IL-2 resulted in reduced expression of these cytokine-responsive genes.

In summary, expression trends in healthy $\mathrm{T}_{\text {regs }}$ under cytokine deprivation were identical to those observed in $T_{\text {regs }}$ from T1D subjects. These lines of evidence support the hypothesis that the expression signature in $\mathrm{T}_{\text {regs }}$ from T1D subjects may be partially induced by a cytokine deficient milieu. A pathway diagram in Figure 6 captures the multiple signaling events that could trigger apoptosis in $\mathrm{T}_{\text {regs }}$ from $\mathrm{T} 1 \mathrm{D}$ subjects, under conditions of cytokine deprivation.

\section{Discussion}

IL-2, a T-cell growth factor, plays an important role in multiple aspects of T-cell biology. Apart from the effect of IL-2 on $\mathrm{T}_{\text {reg }}$ activation, there is strong evidence supporting a role for IL-2 in the development and/or function of $\mathrm{T}_{\text {regs }}[25,26,43]$. In close proximity to $\mathrm{T}_{\text {regs }}$ in vivo, are effector $\mathrm{T}$-cells which control $\mathrm{T}_{\text {reg }}$ development and function by secreting several cytokines, including IL-2. There is evidence for an imbalance in cytokine secretion from effector cells in T1D [44]. In the murine TSl $\alpha \beta$ cell line, following IL-2-deprivation, there was decreased proliferation and increased apoptosis over time [45]. Some studies have reported decreased IL-2 production in recent-onset T1D patients and low IL-2 production persisting for years after the onset of disease $[46,47] . T_{\text {reg stimulation occurs in vivo by cytokines secreted from }}$ various effector cell types, but the $\mathrm{CD} 4+$ effector $\mathrm{T}$ cells which are the major producers of IL-2, play a primary role in shaping the $\mathrm{T}_{\text {reg }}$ maturation and response. We also compared the production of cytokines in both the $\mathrm{CD} 4^{+} \mathrm{CD} 25^{-}$and the $\mathrm{CD} 4^{+} \mathrm{CD} 25^{\text {low }}$ effector T-cell subsets from T1D and control subjects. As shown in Figure S3, for both these effector T-cell subsets, after 12 hours of $\alpha \mathrm{CD} 3$ and $\alpha \mathrm{CD} 28$ stimulation, production of some important cytokines (IL-2, IL-4, IL-5, IL-10, IFN $\gamma$ and TNF $\alpha$ ) was reduced in T1D subjects compared to control subjects, with the maximum difference in levels of IL-2 secretion $(p<0.05$ for IL-2, $\mathrm{CD} 4^{+} \mathrm{CD} 25^{-}$). Further, although differences in the production of other cytokines across the two groups were not statistically significant, the trends were similar for each of the measured cytokines. These results collectively suggest that increased apoptosis, decreased $\mathrm{T}_{\text {reg }}$ function and concomitant gene expression changes could be linked to deficient IL-2 secretion from effector T-cells.

In line with this hypothesis, we observed elevated $\mathrm{T}_{\text {reg }}$ apoptosis and reduced $\mathrm{T}_{\text {reg }}$ suppressive function at the onset of disease. Considering that $\mathrm{T}_{\text {regs }}$ are selective targets for destruction, expression profiling within $\mathrm{T}_{\text {regs }}$ provided us with a model for understanding the cause ( $\mathrm{T}_{\text {reg }}$ environment) by studying the effect ( $\mathrm{T}_{\text {reg }}$ expression changes). Our data supports the notion that in patients with T1D, the lack of suppression of autoreactive T-cells in the periphery is a result of increased apoptosis in $T_{\text {regs }}$, possibly precipitated by deprivation of growth signals such as IL-2. Increased expression of various apoptosis genes, and the downregulation of pro-survival GIMAP genes indicate a complex interplay amongst these pathways leading to apoptosis. Further, co-ordinate repression of cytokine receptors and HLA genes points to a possible proliferation defect in $\mathrm{T}_{\text {regs }}$ from $\mathrm{T} 1 \mathrm{D}$ subjects.

The FOXO subfamily of forkhead transcription factors plays an evolutionarily conserved role in cellular adaptation to stress stimuli and also regulates survival in response to cytokine deprivation, DNA damage and oxidative stress. Amongst several reports documenting apoptosis of lymphoid cells under conditions of cytokine deprivation $[48,49]$, there is increasing evidence for the involvement of the PI3K/AKT and the closely intertwined p53 signaling pathways [50-53]. Further reports have shown that under conditions of cytokine deprivation mediated cellular stress, AKT-mediated activation of FOXO3A and subsequent transcriptional regulation by FOXO3A leads to cell cycle arrest and apoptosis [54,55]. In $\mathrm{T}_{\text {regs }}$ from $\mathrm{T} 1 \mathrm{D}$ subjects, we observe $A K T$ to be downregulated, while PTEN and FOXO3A are upregulated, suggesting that in the absence of activated AKT, FOXO3A phosphorylation may be inhibited, which could lead to its activation and translocation to the nucleus. Transcriptionally active $F O X O 3 A$ induces several pro-apoptotic genes such as PUMA, BIM, GADD45A, GADD45B, SESN1, TNFRSF10B, CIT$E D 2$ and $C D K N 1 B$, all of which were upregulated in $\mathrm{T}_{\text {regs }}$ from T1D subjects (significant either on the array at $\mid z$-score $\mid>20$ or on RT-PCR at $\mathrm{p}<0.05$ ) as well as show similar trends in healthy $\mathrm{T}_{\text {regs }}$ under conditions of IL-2 withdrawal. Our data suggests that in $\mathrm{T}_{\text {regs }}$ from $\mathrm{T} 1 \mathrm{D}$ subjects, both the AKT and $\mathrm{p} 53$ pathways exert pro-apoptotic function through transcriptional regulation of multiple downstream targets that render the cells sensitive to apoptosis.

Few studies have reported on the expression of HLA molecules in T-cells of patients with T1D. HLA class I expression has been 

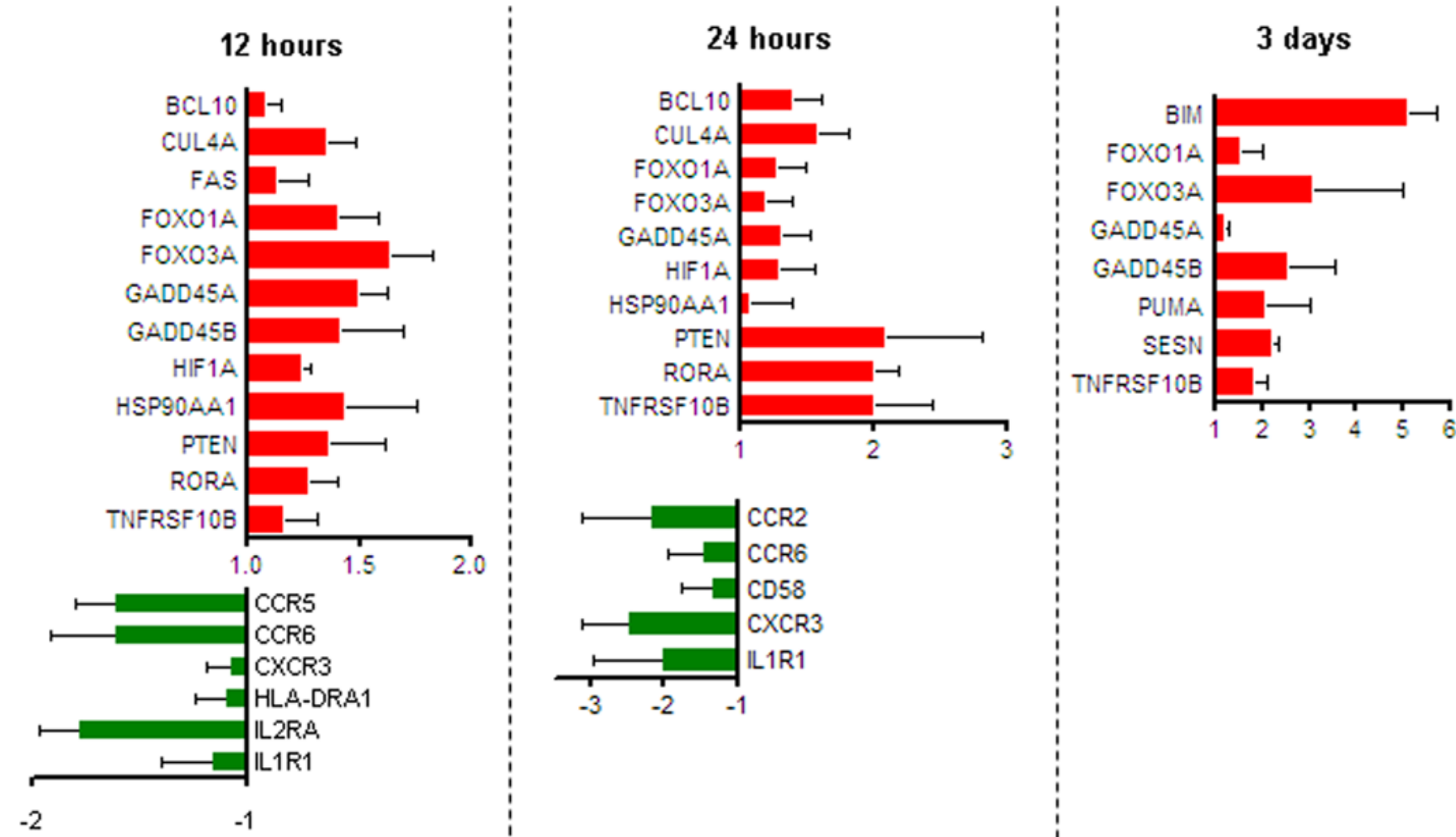

\section{Fold change [(TCR.Co+anti-IL2)/TCR.Co]}

Figure 5. Under condition of IL-2 withdrawal, expression changes of key apoptosis and cytokine/chemokine genes in healthy $\mathbf{T}_{\text {regs }}$ are similar to those observed in $T_{\text {regs }}$ from T1D subjects. Expression changes in 32 selected genes were captured in healthy $T_{\text {regs }}$ treated with $\mathrm{aCD} 3+\mathrm{aCD} 28$ with or without anti-IL-2, for indicated time points. The figure shows a subset of apoptosis and cytokine/chemokine receptor genes, whose expression trends in IL-2-deprived healthy $\mathrm{T}_{\text {regs }}$ were similar to those in $\mathrm{T}_{\text {regs }}$ from T1D subjects. Red bars indicate genes upregulated on IL-2 deprivation and green bars indicate genes downregulated on IL-2 deprivation in healthy $T_{\text {regs }}$. The bars depict the mean \pm SEM of three independent observations.

doi:10.1371/journal.pone.0006527.g005

reported to be decreased [56] or normal [57,58], whereas HLA class II expression on the surface of PBMC of T1D patients has been reported to be normal [56]. Reduced expression of HLA Class I as well as Class II molecules in freshly isolated $\mathrm{T}_{\text {regs }}$ from T1D subjects could lead to defects in HLA-TCR interactions between $\mathrm{T}_{\text {regs }}$ and various other $\mathrm{T}$-cell subsets in the periphery. Recently, it has been demonstrated that the direct ex vivo expression of HLA-DR in the context of $\mathrm{CD} 44^{+} \mathrm{CD} 25^{\text {high }} \mathrm{T}$ cells identifies a mature, functionally distinct regulatory $\mathrm{T}$ cell population involved in contact-dependent in vitro suppression[59]. Our observation of reduced HLA Class II in $\mathrm{T}_{\text {regs }}$ from T1D subjects and the associated loss of suppressive capacity is in line with this report. We are currently following up this relationship across HLA expression, $\mathrm{T}_{\text {reg }}$ function and genotype as a separate study.

Several genes in the GIMAP family of novel GTPases (GIMAP4, GIMAP5, GIMAP1, GIMAP7 and GIMAP8) are also downregulated in $\mathrm{T}_{\text {regs }}$ from T1D subjects. Recent reports suggest crucial roles of GIMAP family proteins in regulating T-cell development, selection and homeostasis [60,61], and GIMAP4/5 have been shown to interact with BCL2 family members, thereby regulating T-cell survival [39]. GIMAP5 gene mutations have been shown to contribute to T1D in the rat model for diabetes [62,63]. As the downregulation of GIMAP genes in $\mathrm{T}_{\text {regs }}$ from $\mathrm{T} 1 \mathrm{D}$ subjects could not be reproduced in healthy $\mathrm{T}_{\text {regs }}$ under IL-2 withdrawal, the IL2 pathway does not seem to control expression of GIMAP genes.
It is interesting to observe that some of the differentially expressed genes in this study have been discussed in other $\mathrm{T}_{\text {reg }}$ gene expression studies, in both the physiological and disease contexts. Amongst a subset of direct FOXP3 targets that exhibited consistent transcriptional behavior in hybridomas and in ex vivo $\mathrm{T}$ cells [64], we found several negative targets of FOXP3 (EVI2B, GADD45B, PTPN22, TGIF, MYC, PHF6, POU2AF1 and GPR171) to be upregulated in $\mathrm{T}_{\text {regs }}$ from T1D subjects while positive FOXP3 targets (IL2RA, CD2 and CPEB2) were downregulated in $\mathrm{T}_{\text {regs }}$ from T1D subjects. In summary, our results provide evidence that dysregulation in $\mathrm{T}_{\text {reg }}$ specific as well as FOXP3 associated genes could lead to functionally compromised $T_{\text {regs }}$ in T1D subjects.

Our study design has some limitations. First, Our $\mathrm{T}_{\text {reg }}$ isolation strategy may not be the most optimal way to isolate pure $\mathrm{T}_{\text {regs }}$. However, isolation of bonafide regulatory $\mathrm{T}$-cells remains difficult because the availability of specific marker molecules is still limited. Apart from CD25, additional surface molecules have been proposed as useful markers to distinguish regulatory from effector T-cells, such as GTLA4, TNFRSF18 (GITR), GD62L and NRP1. However, many of these molecules are also expressed by naïve $\mathrm{CD} 4^{+} \mathrm{CD} 25^{-}$T-cells upon activation, thereby hampering discrimination between regulatory and conventionally activated $\mathrm{CD}^{+}{ }^{+} \mathrm{T}$-cells. Here we adopted a very conservative $\mathrm{T}_{\text {reg }}$ isolation strategy, selecting only the top $1 \%$ CD25 expressing cells as $\mathrm{T}_{\text {regs. }}$. The additional confirmation that most of these cells were CD127- 


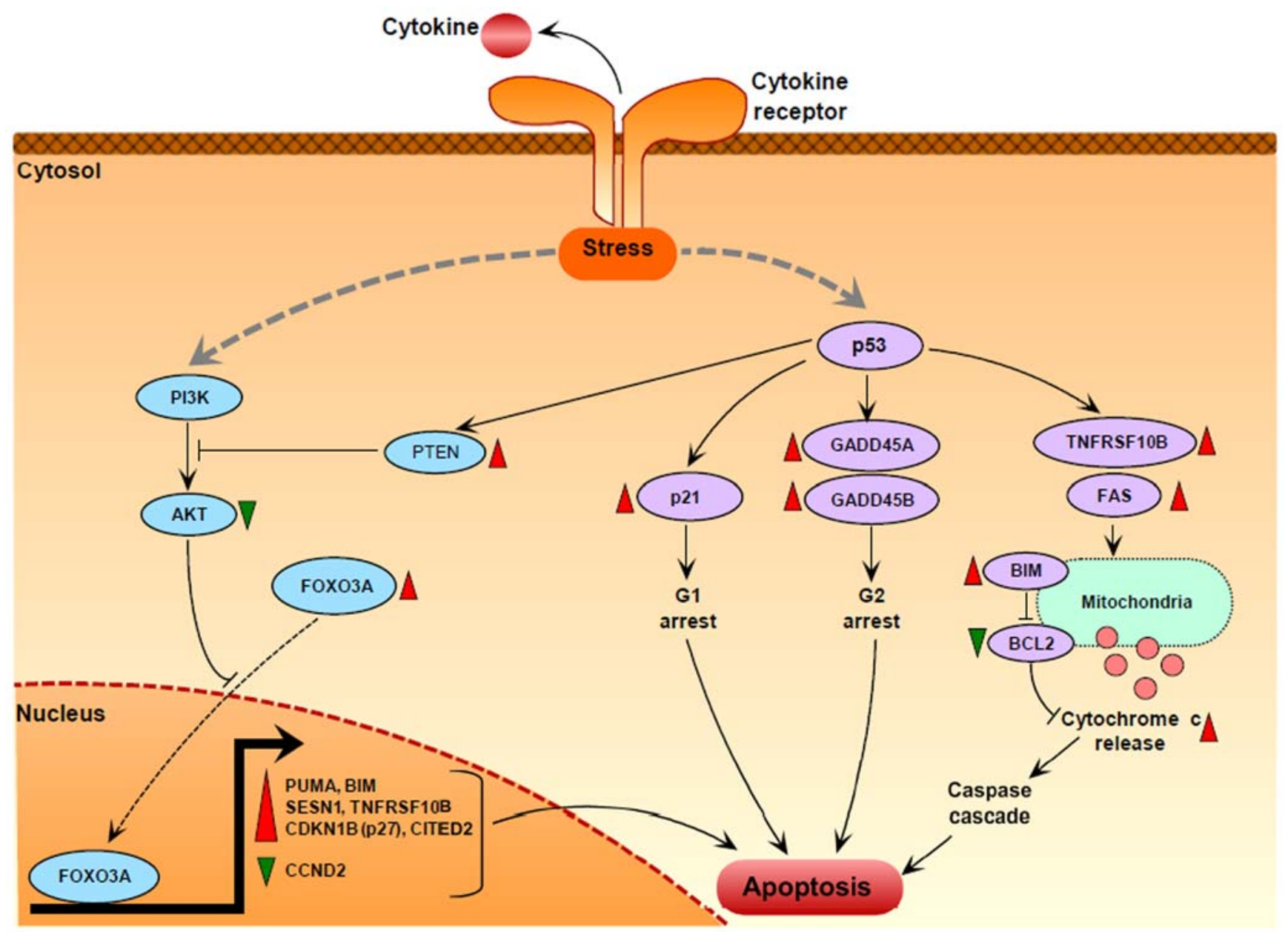

Figure 6. Putative cytokine deprivation mediated apoptosis signaling pathways in $T_{\text {regs }}$ from T1D subjects. In the absence of cytokines or growth factors, the stress-induced PI3K-AKT pathway and the p53 pathway are activated. Downregulation of PI3K and AKT through inhibition by PTEN leads to translocation of dephosphorylated FOXO3A into the nucleus. Nuclear FOXO3A activates several pro-apoptotic genes (PUMA, BIM, SESN1, TNFRSF10B, CDKN1B, CITED2) and represses CCND2 (a cell cycle gene) by direct transcriptional control. Modulation of these FOXO3A targets then leads to cell cycle arrest and apoptosis. On the other hand, activation of p53 further represses AKT via induction of PTEN, and also leads to a cascade of expression changes in several apoptosis genes. Activation of p21 and the two GADD45 genes leads to cell cycle arrest at the G1 and G2 phases respectively. Ligation of TRAIL with TNFRSF10B (TRAILR) and activation of FAS on the surface of $\mathrm{T}_{\text {regs }}$ triggers the extrinsic apoptosis pathway, leading to the release of cytochrome $\mathrm{c}$ from the mitochondria and activation of the caspase cascade. This complex signaling involving cytokinedeprivation mediated activation of both the intrinsic pathway as well as the extrinsic pathway leads to increased $T_{\text {reg }}$ apoptosis in T1D subjects. Genes with red triangles were upregulated, while genes with green triangles were downregulated in $T_{\text {regs }}$ from T1D subjects (|z-score|>20 on the array). This pathway diagram is constructed using known gene-gene interactions from the literature, for those genes that were discussed in this study either on the array, RT-PCR or under conditions of IL-2-deprivation.

doi:10.1371/journal.pone.0006527.g006

ve ensures that our cell population is highly enriched for $\mathrm{T}_{\text {regs }}$ (Figure S4-A). Second, subjects in both groups belonged to different age groups. However, we have earlier shown that the apoptosis of $\mathrm{T}_{\text {regs }}$ is not related to age effects [65]. Third, although it would be more useful to confirm the results on apoptosis and cytokine receptor genes directly on $\mathrm{T}_{\text {regs }}$ from $\mathrm{T} 1 \mathrm{D}$ subjects, we had to use healthy $\mathrm{T}_{\text {reg }}$ blood-donor subjects for lack of adequate numbers of fresh $\mathrm{T}_{\text {regs }}$ from children with $\mathrm{T} 1 \mathrm{D}$. Further, subjecting $\mathrm{T}_{\text {regs }}$ from T1D subjects to IL-2 deprivation would have not have much use, as they are already in an environment of cytokine deprivation. Nevertheless, the expression of pro-apoptotic genes in $\mathrm{T}_{\text {regs }}$ from healthy subjects under conditions of IL-2 deprivation mimicked the behavior of the same genes in $\mathrm{T}_{\text {regs }}$ from T1D subjects, which gives indirect yet convincing evidence in support of our hypothesis. Lastly, with this study design, it is not possible to determine precisely the extent to which the expression profile associated with the T1D phenotype could be mediated by possible secondary effects of insulin or hyperglycemia. However, we have previously shown that long-standing T1D subjects as well as longstanding T2D subjects who are also on insulin do not show the same $\mathrm{T}_{\text {reg }}$ defects as in the at-risk or recent-onset $\mathrm{T} 1 \mathrm{D}$ subjects [10]. Hence, it is unlikely that there is any significant effect of exogenous insulin or hyperglycemia on $\mathrm{T}_{\text {reg }}$ apoptosis.

To conclude, this report establishes the expression signature within $\mathrm{T}_{\text {regs }}$ in the periphery, during the period right after the clinical onset of T1D. $T_{\text {regs }}$ in T1D subjects express several proapoptotic genes, specifically along the AKT- and p53- signaling axis, which may be partially a result of cytokine deprivation. This identification of a molecular signature of $\mathrm{T}_{\text {regs }}$ during the recentonset T1D period is an important step in understanding $\mathrm{T}_{\text {reg }}$ action and could serve as an important diagnostic for $\mathrm{T}_{\text {regs }}$ that have lost the potential to suppress autoreactive effector cells. 
Understanding the mechanism by which cytokine deprivation in T1D induces expression of apoptotic genes will reveal novel points along the death-promoting cascade, which can be targeted for therapeutic interventions.

\section{Materials and Methods}

\section{Ethics Statement}

The research protocol was approved by the Institutional Review Board (IRB) of the Children's Hospital of Wisconsin IRB no. 0115 and participants and/or their parents (guardians) provided written informed consent.

\section{Human subjects and clinical measurements}

Recent-onset T1D subjects (after stabilization on exogenous insulin but within 12 months of diagnosis; $n=15$ ) were recruited through the diabetes program at Children's Hospital of Wisconsin. Diabetes was defined according to World Health Organization criteria and included blood glucose levels of $>200 \mathrm{mg} / \mathrm{dl}$ with symptoms confirmed by a physician [66]. Healthy control $(n=17)$ subjects were recruited by posting flyers in Children's Hospital of Wisconsin and the Medical College of Wisconsin. The control criteria comprised fasting blood glucose of $<100 \mathrm{mg} / \mathrm{dl}$, no familial history of any autoimmune disorder, and negativity for islet autoantibodies at the 99th percentile. All study subjects were free of known infection at the time of sample collection. At the time of each visit, the following clinical measurements were taken: HbAlc, glucose level, height, weight and BMI (subject characteristics are shown in Table 2). The presence of autoantibodies was measured from peripheral blood.

\section{$\mathrm{CD} 4^{+} \mathrm{CD} 25^{\text {high }} \mathrm{T}$-cell isolation}

As this study assessed whether alterations in the function of regulatory T-cells could be involved in the pathogenesis of T1D, it was crucial to identify highly pure and homogeneous regulatory $\mathrm{T}$ cells. It is now known that while the entire population of $\mathrm{CD} 4{ }^{+} \mathrm{CD} 25^{+} \mathrm{T}$-cells, expressing both low and high CD25 exhibits regulatory function in the mouse, only the $\mathrm{CD} 4^{+} \mathrm{CD} 25^{\text {high }}$ population exhibits a similarly strong regulatory function in humans [67-69]. Using the same FACS isolation protocol described earlier [10], we collected the top $1 \%$ of $\mathrm{CD} 4^{+} \mathrm{CD} 25^{\text {high }}$ $\mathrm{T}$-cells as $\mathrm{T}_{\text {regs }}$ for this study. $\mathrm{CD} 4^{+} \mathrm{CD} 25^{\text {low }}$ and $\mathrm{CD} 4^{+} \mathrm{CD} 25^{-}$ effector $\mathrm{T}$ cells were also isolated using the same protocol. This additional stringency of collecting just the top $1 \%$ of $\mathrm{CD} 4^{+} \mathrm{CD} 25^{\text {high }}$ cells as $\mathrm{T}_{\text {regs }}$ ensured removal of most of the activated CD25 ${ }^{\text {low }}$ T-cells. We found that most of the $\mathrm{T}_{\text {regs }}$ we isolate are CD127-ve [70,71], while most of the CD4 ${ }^{+} \mathrm{CD} 25^{-}$cells are $\mathrm{CD} 127^{+}$, as an added confirmation of the purity of the isolated $\mathrm{T}_{\text {regs. }}$. See Supporting Fig. S5-A for a representative plot of this standardized sorting procedure. Further, as shown in Figure S4-B, intracellular staining for FOXP3 positivity also showed that $\mathrm{T}_{\text {regs }}$ isolated using this protocol had a significantly higher percentage of $\mathrm{FOXP}^{+}$cells $(61.88 \pm 2.68)$ compared to CD4+CD2 $\overline{5}$ cells (4.32 \pm 0.80$)$ (Mann-Whitney $\mathrm{p}<0.0001)$. Isolated $\mathrm{T}_{\text {reg }}$ cells were anergic and showed good suppressive capacity in vitro (data not shown). Thus, our isolation protocol generated $\mathrm{T}_{\text {regs }}$ that maintained high level of sustained FOXP3 expression associated with phenotypic and functional stability.

\section{RNA extraction and hybridization}

Total RNA was extracted from $\mathrm{CD} 4^{+} \mathrm{CD} 25^{\text {high }} \mathrm{T}$-cells using TRIzol Reagent (Invitrogen Life Technologies) according to the manufacturer's protocol. The GeneChip human genome U133 plus 2.0 array (Affymetrix) was selected for this study which interrogates $>47,000$ probe sets, representing roughly 39,000 unique genes. Purified total RNA ( $\sim 50 \mathrm{ng})$ was amplified using an Affymetrix two-cycle cDNA synthesis kit (catalog no. 900432) and cRNA was synthesized, labeled, fragmented and hybridized to the arrays in accordance to standard Affymetrix protocols. After hybridization arrays were washed, stained with PE-conjugated streptavidin (Molecular Probes) and scanned on a GeneChip Scanner 3000 (Affymetrix). Image data were analyzed with Affymetrix GeneChip operating software (GCOS).

\section{Microarray quality control}

Each microarray scan was visually inspected for irregularities, and the quality of the entire microarray set was assessed using the affy QCreport package from the Bioconductor project [72]. Information from the various QC plots (Figure S5) confirmed good data quality across arrays.

\section{Bayesian hierarchical analysis}

Most existing methods for studying differential expression adopt a stepwise procedure for obtaining a point estimate of expression for each gene on each array. Having obtained point estimates for all the genes, studies of differential expression between pairs of

Table 2. Subject demographics and clinical measurements.

\begin{tabular}{|c|c|c|}
\hline & Recent-onset T1D & Healthy Controls \\
\hline Number of subjects & 12 & 15 \\
\hline Gender & $4 \mathrm{M} / 8 \mathrm{~F}$ & $5 \mathrm{M} / 7 \mathrm{~F}$ \\
\hline Age at visit (years) & $13 \pm 5$ & $35 \pm 14$ \\
\hline Height $(\mathrm{cm})$ & $153 \pm 19$ & $169 \pm 9$ \\
\hline Weight (kg) & $47 \pm 18$ & $67 \pm 14$ \\
\hline BMI & $19 \pm 3$ & $23 \pm 3$ \\
\hline Glucose (mg/dl) & $203 \pm 79$ & $87 \pm 12$ \\
\hline Duration of T1D (months) (range: $0.48-10.56$ ) & $4.4 \pm 3.3$ & NA \\
\hline HbA1c (\%) & $7 \pm 0.8$ & NA \\
\hline Insulin dose (ave.units/kg/day) (range: $0.05-0.75$ ) & $0.46 \pm 0.27$ & NA \\
\hline NA $=$ Not Applicable & & \\
\hline
\end{tabular}


phenotypes are carried out by comparing the collections of point estimates under the phenotypes, using a t-type statistic such as in SAM [73], Cyber-T [74] or Limma [75], all of which rely on the availability of replicate subjects in each phenotypic condition, for estimation of variances. These approaches are not feasible when the number of subjects is low. As limitations on the amount of available RNA restricted our analysis study to a limited number of subjects in each phenotype, we used Bayesian Gene eXpression, BGX [76-78], which implements a statistical procedure that works with minimal or no replicates in each phenotypic group. The BGX method differs from these stepwise point estimate approaches in that (1) uncertainties associated with each of the steps are taken into account at all levels of analysis, (2) gene- and phenotypespecific expression levels are estimated from a joint consideration of the available probe set intensities and (3) the outcomes are posterior distributions of expression rather than point estimates. A flowchart for all steps of this analysis is shown in Figure S6. The program was executed with the following parameter values: number of probes: 604258; number of genes: 54675; number of categories: 1, number of probes with no sequence information: 0 ; number of genes to monitor fully: 0 ; sub-sampling interval: 16; number of burn-in sweeps: 8192; number of sampling sweeps: 16384; spread of jumps in S: 30; spread of jumps in $\mathrm{H}$ : 350; spread of jumps in mu: 1.1; spread of jumps in sigma: 1.5; spread of jumps in lambda: 0.04; spread of jumps in eta: 0.1; batch size: 50 and optimal acceptance ratio: 0.44 . Briefly, in the first step, a Bayesian hierarchical model is formulated for estimating expression levels from probe level expression data from all the arrays. For each gene in each phenotype (phenotype 1: T1D and phenotype 2: Control), the gene expression index $\mu_{\mathrm{g} 1}$ (level of expression of gene $\mathrm{g}_{\mathrm{g}}$ in T1D) and $\mu_{\mathrm{g} 2}$ (level of expression of gene $\mathrm{g}$ in Controls) is calculated. Within this framework, the samples from the posterior distributions of the differences $\left(d_{g}=\mu_{g, 1}-\mu_{g, 2}, g=1, \ldots 54675\right)$ represent a natural base for inference on differential expression. For each gene, a kernel density plot for the expression index $\mu_{g p}$ and the difference $d_{g}$ was constructed. From the cumulative information of expression differences $\left(d_{g}, \mathrm{~g}=1\right.$ to 54675), a histogram of the posterior probabilities of expression differences being less than zero $\left[P\left(d_{g}<0\right), \mathrm{g}=1, \ldots 54675\right]$ is determined (Figure $\mathrm{S} 7$ ). The null distribution is estimated by spline fitting [79] on the histogram, and the difference between the histogram fit (grey curve) and the null distribution (black curve) is used to give an estimate of the number of differentially expressed genes. An excess of $P\left(d_{g}<0\right)$ values in the left as well as right tails indicates the presence of both over- and under-expressed genes respectively. In the final step, genes are ranked using the standardized BGX difference (z-score) between the two conditions, which takes into account the estimated difference in expression level as well as the associated uncertainty. The z-score also takes into account the autocorrelation structure of the sequence of values generated by the algorithm, whereby genes with highly autocorrelated values (high variability) are automatically given lower ranks, thereby increasing the power to detect differential expression. The identities of the differentially expressed genes are found by selecting from each end of the ranked list, the number of differentially expressed genes predicted to be in the tails of the histogram of posterior probabilities. The analysis predicted a total of 1205 differentially expressed genes, of which 948 genes were upregulated in T1D (left tail of the histogram) and 257 genes were downregulated in T1D (right tail of the histogram). Although rank thresholds from the histogram were used instead of an arbitrary z-score threshold for picking differentially expressed genes, all genes within the list of 1205 differentially satisfied the $\mid z$-score $\mid>20$ threshold, which has been shown to yield a low $<5 \%$ FDR on the Golden spike control dataset [76]. There was a 78\% overlap among differentially expressed genes predicted through BGX $($ FDR $<5 \%)$ and SAM $(\mathrm{t}-$ test, $\mathrm{FDR}<9.5 \%$ ), which verifies the predictive accuracy of this new Bayesian technique, when compared to a frequentist approach. These data have been deposited in NCBI's Gene Expression Omnibus (GEO, http://www.ncbi.nlm.nih.gov/geo/) and are accessible through GEO Series accession number GSE10586.

\section{Gene annotation and pathway enrichment analysis}

Gene annotation was carried out using controlled vocabularies from the Gene Ontology database [80]. Information from genegene interactions on multiple KEGG pathways (http://www. genome.jp/kegg) was assimilated for constructing the putative signaling diagram shown in Fig. 6. Pathway enrichment analysis was carried out using EASE [35]. Briefly, in EASE, the following terminology is used for pathway enrichment analysis: List Hits = number of genes in the gene list that belong to the Gene Category; List Total $=$ number of genes in the gene list; Population Hits = number of genes in the total group of genes assayed that belong to the specific Gene Category; Population Total = number of genes in the total group of genes assayed that belong to any Gene Category within the System. The first step is the mapping of primary gene identifiers to gene categories within various categorical systems. Then, the "Population Total" is determined for each system of gene categorization, and the "Population Hits" is determined for every category within those systems. Now given a gene list that represents some sub-set of the population genes, the "List total" and "List Hits" counts can be determined. The probability of seeing the number of "List Hits" in the "List Total" given the frequency of "Population Hits" in the "Population Total" is calculated as the EASE score. The EASE score is essentially a sliding-scale, conservative adjustment of the Jackknife Fisher exact probabilities that strongly penalizes the significance of categories supported by few genes and negligibly penalizes categories supported by many genes, therefore yielding more robust results.

\section{Real-Time PCR analysis}

Total RNA (25 to $50 \mathrm{ng}$ ) was converted to cDNA using the QuantiTect ${ }^{\circledR}$ reverse transcription kit (Qiagen). Real-time PCR was then performed using the QuantiTect ${ }^{\circledR}$ SYBR Green PCR Kit (Qiagen) on an ABI Prism 7900HT sequence detection system machine with SDS software (Applied Biosystems). Manufacturer protocols were followed for all procedures. mRNA geneexpression was quantified relative to either GAPDH or $18 \mathrm{~s}$ rRNA housekeeping genes. Using the Oligo 6 software (Molecular Biology Insights), primer sets for each gene were designed towards the same region of cDNA that was represented by the probe sets on the Affymetrix GeneChip arrays.

\section{Apoptosis assay}

Apoptosis was measured using a dual-staining method that our group has reported to be very sensitive for apoptosis detection [81]. Briefly, 15,000-25,000 CD4 $4^{+} \mathrm{CD} 25^{\text {high }} \mathrm{T}$-cells were stained with YOPROl $(250 \mathrm{nM})$ for 20 minutes in the dark and 7AAD (250 ng) was added 10 minutes before acquiring events on a FACS LSRII (BD Biosciences). The data was then analyzed using the FACSDiva Software (BD Biosciences). Apoptosis was measured as the percentage of apoptotic cells YOPRO1+ve/7AAD-ve amongst live cells (total 7AAD-ve cells comprising both YOPRO1+ve and YOPRO1-ve cells). 


\section{Suppression assay}

$\mathrm{CD} 4^{+} \mathrm{CD} 25^{-}$T-cells $\left(2.5 \times 10^{4}\right.$ cells/well $)$ were cultured in RPMI 1640 media supplemented with $2 \mathrm{mM} \mathrm{L-glutamine,}$ $5 \mathrm{mM}$ HEPES, $100 \mathrm{U} / \mu \mathrm{g} / \mathrm{ml}$ penicillin/streptomycin, $0.5 \mathrm{mM}$ sodium pyruvate and $10 \%$ human $\mathrm{AB}$ serum. Cells were stimulated with $\alpha \mathrm{CD} 3$ coated beads $(1 \mu \mathrm{g} / \mathrm{ml}, 3$ beads/cell $)$ in U-bottom 96 well plates (Costar) in the presence of the same number of irradiated autologous PBMC for 5 days. For the suppression assays $\mathrm{CD} 4^{+} \mathrm{CD} 25^{\text {high }} \mathrm{T}$-cells were co-cultured with $\mathrm{CD} 4{ }^{+} \mathrm{CD} 25^{-}$at a $1: 10$ ratio $\left(\mathrm{T}_{\text {reg }}: \mathrm{CD} 25^{-} \mathrm{T}_{\text {eff }}\right)$ using the same stimuli. Cells were pulsed with $1 \mu \mathrm{Ci}$ of $\left[{ }^{3} \mathrm{H}\right]$ thymidine (Amersham Pharmacia Biotech) and harvested after 16 hours. The cpm per well was determined with a scintillation counter (Top Count NXT, Packard). The percentage of suppression was calculated as $\{(\mathrm{s}-\mathrm{c}) / \mathrm{s}\} \times 100 \%$, where $\mathrm{s}=\mathrm{cpm}$ in single culture and $\mathrm{c}=\mathrm{cpm}$ in co-culture.

\section{Intracellular Staining for FOXP3}

Intracellular staining for FOXP3 was carried out in 15,00025,000 CD4 ${ }^{+} \mathrm{CD} 25^{\text {high }}$ T-cells using the PE Anti-Human FOXP3 Staining Set (eBioscience) following the recommended protocol. Cells were first fixed, washed and permeablized, then stained with either FOXP3-PE (clone PCH101) or the isotype control rat IgG2a-PE. Intracellularly stained cells were then analyzed on a FACS LSRII using FACSDiva Software (BD Biosciences).

\section{Cytokine measurement from $\mathrm{CD} 4^{+} \mathrm{CD} 25^{\text {low }}$ cells}

$\mathrm{CD} 4^{+} \mathrm{CD} 25^{\text {low }}$ cells were plated at 50,000 cells per well and stimulated with platebound $\alpha \mathrm{CD} 3(5 \mu \mathrm{g} / \mathrm{ml})$ and soluble aCD28 $(2.5 \mu \mathrm{g} / \mathrm{ml})$ (BD Biosciences) at $37^{\circ} \mathrm{C} / 5 \% \mathrm{CO} 2$. After 55 hours, $100 \mathrm{ul}$ of supernatant was removed from each well and stored at $-80^{\circ} \mathrm{C}$ until the cytokines were measured. The supernatants were thawed and $50 \mu \mathrm{l}$ was used in the Cytometric Bead Array (CBA) Human Th1/Th2 Cytokine Kit (BD Biosciences). The assay was performed according to the manufacturer's recommended protocol. The samples were acquired on a FACSCalibur (BD Biosciences) following the cytometer setup protocol. The FACS data was analyzed using the CBA 6 bead analysis software (BD Biosciences).

\section{Apoptosis assay during cytokine deprivation}

$\mathrm{CD} 4^{+} \mathrm{CD} 25^{\text {high }}$ and $\mathrm{CD} 4^{+} \mathrm{CD} 25^{-}$T-cells were isolated from 6 buffy coats by FACS sorting as previously described in the cell isolation procedure above. Cells were plated at 75,000 cells per well under the following 6 conditions: TCR-Co $(1 \mu \mathrm{g} / \mathrm{ml}$ platebound $\alpha \mathrm{CD} 3$, clone UCHT1, Ancell and $0.5 \mu \mathrm{g} / \mathrm{ml}$ soluble aCD28, clone CD28.2, BD Biosciences); TCR-Co+IL-2 (200 U/ $\mathrm{ml}$, human-recombinant, BD Biosciences); TCR-Co+anti-IL-2 (2 $\mu \mathrm{g} / \mathrm{ml}$, clone MQ1-17H12, BD Biosciences); TCR-Co+IL-4 (200 U/ml, recombinant, BD Biosciences); TCR-Co+anti-IL-4 ( $1 \mu \mathrm{g} / \mathrm{ml}$, clone MP4-25D2, BD Biosciences); and TCR-Co+antiIL-2 $(2 \mu \mathrm{g} / \mathrm{ml})+$ anti-IL-4 $(1 \mu \mathrm{g} / \mathrm{ml})$. The cells were incubated at $37^{\circ} \mathrm{C} / 5 \% \mathrm{CO}_{2}$ and at the indicated time points $(12,24,72$ and 120 hours), the cells were removed from the wells and 25,000 cells were used to measure apoptosis as previously described in methods above. The remaining 50,000 cells were resuspended in TRIzol Reagent (Invitrogen) and stored at $-80^{\circ} \mathrm{C}$ until RNA could be isolated.

\section{Supporting Information}

Figure S1 Raw proliferation counts (cpm) for suppression assay. T-cell proliferation (cpm) in media only (background), single culture (only CD25- Teffs) and in co-culture (Tregs and CD25-
Teffs) for both the phenotypic groups is shown for the suppression results shown in Figure 1 in the manuscript. Values shown are mean $\pm \mathrm{SE}$ across the number of samples indicated for Figure 1. Found at: doi:10.1371/journal.pone.0006527.s001 (0.03 MB TIF)

Figure S2 Representative flow cytometry plot for measurement of Treg Apoptosis. Figure shows one representative FACS plot for measurement of Treg apoptosis, as described in the methods section. Apoptosis was measured as the percentage of apoptotic cells YOPRO1+ve/7AAD-ve (green) amongst live cells (total 7AAD-ve cells comprising both YOPRO1+ve and YOPRO1-ve cells, blue+green).

Found at: doi:10.1371/journal.pone.0006527.s002 (0.09 MB TIF)

Figure s3 Cytokine production from CD4+CD25- and CD4+CD25low effector $\mathrm{T}$ cell subsets. Production of some important cytokines was measured by a CBA assay, as described in the methods. Results are average values across indicated number of subjects, for (A) CD4+CD25- and (B) CD4+CD25low effector T-cell subsets.

Found at: doi:10.1371/journal.pone.0006527.s003 (0.03 MB TIF)

Figure S4 Purity of FACS isolated CD4+CD25high T-cells. (A) Standardized sorting procedure based on gating of top $1.2 \%$ CD25-expressing CD4+ T-cells as CD4+CD25high (Tregs). Both CD4+CD25- and CD4+CD25high cell subsets were checked for CD127 expression. Most of CD4+CD25high T-cells do not express CD127 (80.5\%) and most of CD4+CD25- -T-cells do express CD127 (87.1\%). This is representative of 4 samples. (B) Intracellular staining for FOXP3 in CD4+CD25- and CD4+CD25high T-cells.

Found at: doi:10.1371/journal.pone.0006527.s004 (0.04 MB TIF)

Figure S5 Quality assessment of the arrays using AffyQC package. These plots assess the overall signal quality for the arrays. (A) Boxplots of all the pm (perfect match) intensities for 12 T1D subjects (left) and 15 control subjects (right). (B) Density plot of the intensities (log scale) for 12 T1D subjects (left) and 15 control subjects (right). These plots suggest that arrays used in this study are good quality as none of the arrays have a low average intensity or a significantly different shaped density. (C) RNA digestion plot for (left) 15 control subjects and (right) 12 T1D subjects. The mean intensity of expression of all genes on each array is plotted as a function of $5^{\prime}-3^{\prime}$ position of probes. For each array and within each probe-set, probes are arranged by their proximity to the $5^{\prime}$ end of the gene. The plot shows the average intensity of the probes as a function of $5^{\prime}-3^{\prime}$ position of probes. Each line corresponds to an array and the slope of its trend indicates potential RNA degradation of the genetic material hybridized to the array. Parallel lines indicate similar RNA degradation patterns across arrays.

Found at: doi:10.1371/journal.pone.0006527.s005 (0.14 MB TIF)

Figure S6 Flowchart of the gene expression analysis pipeline Found at: doi:10.1371/journal.pone.0006527.s006 (0.03 MB TIF)

Figure S7 BGX measures and estimation of differentially expressed genes. These plots summarise the main steps of the BGX algorithm. (A) Kernel density plots are calculated for the expression of each gene ( $\mathrm{n}=1$ to 54675$)$ in each phenotype, from the cumulative information from all subjects within a phenotype. (B) The corresponding plots of the posterior distribution of the expression differences are calculated for each gene across the two phenotypes. (G) Histogram of the posterior distribution of expression differences. Under the null hypothesis, the histogram of the posterior distribution of expression differences $\mathrm{P}(\mathrm{dg}<0)$ will be unimodal with a mode of 0.5 and have smoothly decreasing 
tails. Towards the two tails of the histogram, the observed deviations from the expected shape indicate the presence of differentially expressed genes. The black curve is the expected distribution (by Efron's method [79]) and the grey curve is the observed distribution. Excess of $\mathrm{P}(\mathrm{dg}<0)$ values near zero and one indicate over-expressed and under-expressed genes in phenotype 2 (T1D subjects) relative to phenotype 1 (Control subjects), respectively. In the final step, genes are ranked using the standardized BGX difference (z-score) between the two conditions, which takes into account the estimated difference in expression level as well as the associated uncertainty.

Found at: doi:10.1371/journal.pone.0006527.s007 (0.06 MB TIF)

\section{Acknowledgments}

The authors thank the physicians, nurses, and staff of Children's Hospital of Wisconsin and The Max McGee National Research Center for Juvenile

\section{References}

1. Tisch R, McDevitt H (1996) Insulin-dependent diabetes mellitus. Cell 85: 291-297.

2. Donath MY, Storling J, Maedler K, Mandrup-Poulsen T (2003) Inflammatory mediators and islet beta-cell failure: a link between type 1 and type 2 diabetes. J Mol Med 81: 455-470.

3. Bacchetta R, Gambineri E, Roncarolo MG (2007) Role of regulatory T cells and FOXP3 in human diseases. J Allergy Clin Immunol 120: 227-235; quiz 236227.

4. Putnam AL, Vendrame F, Dotta F, Gottlieb PA (2005) CD4+CD25high regulatory $\mathrm{T}$ cells in human autoimmune diabetes. J Autoimmun 24: 55-62.

5. Kukreja A, Cost G, Marker J, Zhang C, Sun Z, et al. (2002) Multiple immunoregulatory defects in type-1 diabetes. J Clin Invest 109: 131-140.

6. Lindley S, Dayan CM, Bishop A, Roep BO, Peakman M, et al. (2005) Defective suppressor function in CD4(+)CD25(+) T-cells from patients with type 1 diabetes. Diabetes 54: 92-99.

7. Brusko TM, Wasserfall CH, Clare-Salzler MJ, Schatz DA, Atkinson MA (2005) Functional defects and the influence of age on the frequency of CD4+ CD25+ Tcells in type 1 diabetes. Diabetes 54: 1407-1414.

8. Abdul-Rasoul M, Habib H, Al-Khouly M (2006) 'The honeymoon phase' in children with type 1 diabetes mellitus: frequency, duration, and influential factors. Pediatr Diabetes 7: 101-107.

9. Bonfanti R, Bognetti E, Meschi F, Brunelli A, Riva MC, et al. (1998) Residual beta-cell function and spontaneous clinical remission in type 1 diabetes mellitus: the role of puberty. Acta Diabetol 35: 91-95.

10. Glisic-Milosavljevic S, Waukau J, Jailwala P, Jana S, Khoo HJ, et al. (2007) Atrisk and recent-onset type 1 diabetic subjects have increased apoptosis in the CD4+CD25+ T-cell fraction. PLoS ONE 2: e146.

11. Knoechel B, Lohr J, Zhu S, Wong L, Hu D, et al. (2006) Functional and molecular comparison of anergic and regulatory T lymphocytes. J Immunol 176 : 6473-6483.

12. Pfoertner S, Jeron A, Probst-Kepper M, Guzman CA, Hansen W, et al. (2006) Signatures of human regulatory T cells: an encounter with old friends and new players. Genome Biol 7: R54

13. Sugimoto N, Oida T, Hirota K, Nakamura K, Nomura T, et al. (2006) Foxp3dependent and -independent molecules specific for CD25+CD4+ natural regulatory $\mathrm{T}$ cells revealed by DNA microarray analysis. Int Immunol 18: 1197-1209.

14. Fontenot JD, Gavin MA, Rudensky AY (2003) Foxp3 programs the development and function of CD4+CD25+ regulatory T cells. Nat Immunol 4: $330-336$.

15. Gavin MA, Glarke SR, Negrou E, Gallegos A, Rudensky A (2002) Homeostasis and anergy of CD4(+)CD25(+) suppressor T cells in vivo. Nat Immunol 3: 33-41.

16. Anderson PO, Manzo BA, Sundstedt A, Minaee S, Symonds A, et al. (2006) Persistent antigenic stimulation alters the transcription program in $\mathrm{T}$ cells, resulting in antigen-specific tolerance. Eur J Immunol 36: 1374-1385.

17. Hill JA, Feuerer M, Tash K, Haxhinasto S, Perez J, et al. (2007) Foxp3 transcription-factor-dependent and -independent regulation of the regulatory $\mathrm{T}$ cell transcriptional signature. Immunity 27: 786-800.

18. Herman AE, Freeman GJ, Mathis D, Benoist C (2004) CD4+CD25+ T regulatory cells dependent on ICOS promote regulation of effector cells in the prediabetic lesion. J Exp Med 199: 1479-1489.

19. Chen Z, Herman AE, Matos M, Mathis D, Benoist C (2005) Where CD4+CD25+ T reg cells impinge on autoimmune diabetes. J Exp Med 202: 1387-1397.

20. Kaizer EC, Glaser CL, Chaussabel D, Banchereau J, Pascual V, et al. (2007) Gene Expression in Peripheral Blood Mononuclear Cells from Children with Diabetes. J Clin Endocrinol Metab.
Diabetes who assisted in subject recruitment. Special thanks to Marilyn Koppen and Joanna Kramer for their help in sample collection and processing. We acknowledge Ernest Turro, who provided expert help in the data analysis.

\section{Author Contributions}

Conceived and designed the experiments: SJ SG. Performed the experiments: JW SG SE. Analyzed the data: PJJW SG PWL. Contributed reagents/materials/analysis tools: RA XW. Wrote the paper: PJ SG. Helped in co-ordination of the study: SG. Reviewed the manuscript and provided guidance on this study design: $\mathrm{MH}$. Recruited the T1D subjects and control subjects involved in this study: RA. Reviewed the manuscript and provided guidance on the experimental design: SM. Provided statistical help and guidance in data analysis: PWL. Reviewed the manuscript: XW.

21. Orban T, Kis J, Szereday L, Engelmann P, Farkas K, et al. (2007) Reduced CD4+ T-cell-specific gene expression in human type 1 diabetes mellitus. J Autoimmun 28: 177-187.

22. Furtado GC, Curotto de Lafaille MA, Kutchukhidze N, Lafaille JJ (2002) Interleukin 2 signaling is required for CD4(+) regulatory T cell function. J Exp Med 196: 851-857.

23. Setoguchi R, Hori S, Takahashi T, Sakaguchi S (2005) Homeostatic maintenance of natural Foxp3(+) CD25(+) CD4(+) regulatory $\mathrm{T}$ cells by interleukin (IL)-2 and induction of autoimmune disease by IL-2 neutralization. J Exp Med 201: 723-735.

24. Wolf M, Schimpl A, Hunig T (2001) Control of T cell hyperactivation in IL-2deficient mice by CD4(+)CD25(-) and CD4(+)CD25(+) T cells: evidence for two distinct regulatory mechanisms. Eur J Immunol 31: 1637-1645.

25. Almeida AR, Legrand N, Papiernik M, Freitas AA (2002) Homeostasis of peripheral CD4+ T cells: IL-2R alpha and IL-2 shape a population of regulatory cells that controls CD4+ T cell numbers. J Immunol 169: 4850-4860.

26. Malek TR, Yu A, Vincek V, Scibelli P, Kong L (2002) GD4 regulatory T cells prevent lethal autoimmunity in IL-2Rbeta-deficient mice. Implications for the nonredundant function of IL-2. Immunity 17: 167-178.

27. Thornton AM, Donovan EE, Piccirillo CA, Shevach EM (2004) Cutting edge: IL-2 is critically required for the in vitro activation of CD4+CD25+ T cell suppressor function. J Immunol 172: 6519-6523.

28. de la Rosa M, Rutz S, Dorninger H, Scheffold A (2004) Interleukin-2 is essential for CD4+CD25+ regulatory T cell function. Eur J Immunol 34: 2480-2488.

29. Bayer AL, Yu A, Adeegbe D, Malek TR (2005) Essential role for interleukin-2 for $\mathrm{CD} 4(+) \mathrm{CD} 25(+) \mathrm{T}$ regulatory cell development during the neonatal period. J Exp Med 201: 769-777.

30. Tang Q Adams JY, Penaranda C, Melli K, Piaggio E, et al. (2008) Central role of defective interleukin-2 production in the triggering of islet autoimmune destruction. Immunity 28: 687-697.

31. Yamanouchi J, Rainbow D, Serra P, Howlett S, Hunter K, et al. (2007) Interleukin-2 gene variation impairs regulatory $\mathrm{T}$ cell function and causes autoimmunity. Nat Genet 39: 329-337.

32. Vukmanovic-Stejic M, Zhang Y, Cook JE, Fletcher JM, McQuaid A, et al. (2006) Human CD4+ CD25hi Foxp3+ regulatory T cells are derived by rapid turnover of memory populations in vivo. J Clin Invest 116: 2423-2433.

33. Aswad F, Kawamura H, Dennert G (2005) High sensitivity of CD4+CD25+ regulatory $\mathrm{T}$ cells to extracellular metabolites nicotinamide adenine dinucleotide and ATP: a role for P2X7 receptors. J Immunol 175: 3075-3083.

34. Mootha VK, Lindgren CM, Eriksson KF, Subramanian A, Sihag S, et al. (2003) PGC-1alpha-responsive genes involved in oxidative phosphorylation are coordinately downregulated in human diabetes. Nat Genet 34: 267-273.

35. Hosack DA, Dennis G Jr, Sherman BT, Lane HC, Lempicki RA (2003) Identifying biological themes within lists of genes with EASE. Genome Biol 4: R70.

36. Nakamoto Y, Kaneko S, Kobayashi K (2002) Increased susceptibility to apoptosis and attenuated Bcl-2 expression in $\mathrm{T}$ lymphocytes and monocytes from patients with advanced chronic hepatitis C. J Leukoc Biol 72: 49-55.

37. Chalah A, Khosravi-Far R (2008) The mitochondrial death pathway. Adv Exp Med Biol 615: 25-45.

38. Dalberg U, Markholst H, Hornum L (2007) Both Gimap5 and the diabetogenic BBDP allele of Gimap5 induce apoptosis in T cells. Int Immunol 19: 447-453.

39. Nitta T, Nasreen M, Seike T, Goji A, Ohigashi I, et al. (2006) IAN family critically regulates survival and development of T lymphocytes. PLoS Biol 4: e103.

40. Dion C, Carter C, Hepburn L, Coadwell WJ, Morgan G, et al. (2005) Expression of the Ian family of putative GTPases during T cell development and description of an Ian with three sets of GTP/GDP-binding motifs. Int Immunol 17: $1257-1268$. 
41. Ward SG, Westwick J (1998) Chemokines: understanding their role in Tlymphocyte biology. Biochem J 333 (Pt3): 457-470.

42. Palacios $\mathrm{R}$ (1982) Mechanism of $\mathrm{T}$ cell activation: role and functional relationship of HLA-DR antigens and interleukins. Immunol Rev 63: 73-110.

43. Papiernik M, de Moraes ML, Pontoux C, Vasseur F, Penit C (1998) Regulatory CD4 T cells: expression of IL-2R alpha chain, resistance to clonal deletion and IL-2 dependency. Int Immunol 10: 371-378.

44. Rabinovitch A, Suarez-Pinzon WL (2007) Roles of cytokines in the pathogenesis and therapy of type 1 diabetes. Cell Biochem Biophys 48: 159-163.

45. Fleischer A, Duhamel M, Lopez-Fernandez LA, Munoz M, Rebollo MP, et al. (2007) Cascade of transcriptional induction and repression during IL-2 deprivation-induced apoptosis. Immunol Lett 112: 9-29.

46. Kaye WA, Adri MN, Soeldner JS, Rabinowe SL, Kaldany A, et al. (1986) Acquired defect in interleukin-2 production in patients with type I diabetes mellitus. N Engl J Med 315: 920-924.

47. Giordano C, Panto F, Caruso C, Modica MA, Zambito AM, et al. (1989) Interleukin 2 and soluble interleukin 2-receptor secretion defect in vitro in newly diagnosed type I diabetic patients. Diabetes 38: 310-315.

48. Bosque A, Marzo I, Naval J, Anel A (2007) Apoptosis by IL-2 deprivation in human CD8+ T cell blasts predominates over death receptor ligation, requires Bim expression and is associated with Mcl-1 loss. Mol Immunol 44: 1446-1453.

49. Devireddy LR, Green MR (2003) Transcriptional program of apoptosis induction following interleukin 2 deprivation: identification of RC3, a calcium/calmodulin binding protein, as a novel proapoptotic factor. Mol Cell Biol 23: 4532-4541.

50. Stahl M, Dijkers PF, Kops GJ, Lens SM, Coffer PJ, et al. (2002) The forkhead transcription factor FoxO regulates transcription of p27Kipl and Bim in response to IL-2. J Immunol 168: 5024-5031.

51. Ahmed NN, Grimes HL, Bellacosa A, Chan TO, Tsichlis PN (1997) Transduction of interleukin-2 antiapoptotic and proliferative signals via Akt protein kinase. Proc Natl Acad Sci U S A 94: 3627-3632.

52. You H, Pellegrini M, Tsuchihara K, Yamamoto K, Hacker G, et al. (2006) FOXO3a-dependent regulation of Puma in response to cytokine/growth factor withdrawal. J Exp Med 203: 1657-1663.

53. You H, Yamamoto K, Mak TW (2006) Regulation of transactivationindependent proapoptotic activity of p53 by FOXO3a. Proc Natl Acad Sci U S A 103: 9051-9056.

54. Tran H, Brunet A, Grenier JM, Datta SR, Fornace AJ Jr, et al. (2002) DNA repair pathway stimulated by the forkhead transcription factor FOXO3a through the Gadd45 protein. Science 296: 530-534.

55. Furukawa-Hibi Y, Kobayashi Y, Chen C, Motoyama N (2005) FOXO transcription factors in cell-cycle regulation and the response to oxidative stress. Antioxid Redox Signal 7: 752-760.

56. Faustman D, Li XP, Lin HY, Fu YE, Eisenbarth G, et al. (1991) Linkage of faulty major histocompatibility complex class I to autoimmune diabetes. Science 254: $1756-1761$.

57. Hao W, Gladstone P, Engardt S, Greenbaum C, Palmer JP (1996) Major histocompatibility complex class I molecule expression is normal on peripheral blood lymphocytes from patients with insulin-dependent diabetes mellitus. J Clin Invest 98: 1613-1618.

58. Anal O, Akkoc N, Sen A, Yesil S, Yuksel F, et al. (1997) MHC class I antigen expression in patients with IDDM and their siblings. J Pediatr Endocrinol Metab 10: 391-394.

59. Baecher-Allan C, Wolf E, Hafler DA (2006) MHC class II expression identifies functionally distinct human regulatory T cells. J Immunol 176: 4622-4631.

60. Nitta T, Takahama Y (2007) The lymphocyte guard-IANs: regulation of lymphocyte survival by IAN/GIMAP family proteins. Trends Immunol 28: 58-65.

61. Kupfer R, LangJ, Williams-Skipp C, Nelson M, Bellgrau D, et al. (2007) Loss of a gimap/ian gene leads to activation of NF-kappaB through a MAPKdependent pathway. Mol Immunol 44: 479-487.
62. MacMurray AJ, Moralejo DH, Kwitek AE, Rutledge EA, Van Yserloo B, et al. (2002) Lymphopenia in the BB rat model of type 1 diabetes is due to a mutation in a novel immune-associated nucleotide (Ian)-related gene. Genome Res 12: $1029-1039$.

63. Hornum L, Romer J, Markholst H (2002) The diabetes-prone BB rat carries a frameshift mutation in Ian4, a positional candidate of Iddml. Diabetes 51: 1972-1979.

64. Marson A, Kretschmer K, Frampton GM, Jacobsen ES, Polansky JK, et al. (2007) Foxp3 occupancy and regulation of key target genes during T-cell stimulation. Nature 445: 931-935.

65. Glisic-Milosavljevic S, Wang T, Koppen M, Kramer J, Ehlenbach S, et al. (2007) Dynamic changes in CD4+ CD25+(high) T cell apoptosis after the diagnosis of type 1 diabetes. Clin Exp Immunol 150: 75-82.

66. Alberti KG, Zimmet PZ (1998) Definition, diagnosis and classification of diabetes mellitus and its complications. Part 1: diagnosis and classification of diabetes mellitus provisional report of a WHO consultation. Diabet Med 15: 539-553.

67. Piccirillo CA, Letterio JJ, Thornton AM, McHugh RS, Mamura M, et al. (2002) $\mathrm{CD} 4(+) \mathrm{CD} 25(+)$ regulatory $\mathrm{T}$ cells can mediate suppressor function in the absence of transforming growth factor betal production and responsiveness. J Exp Med 196: 237-246.

68. Jonuleit H, Schmitt E, Kakirman H, Stassen M, Knop J, et al. (2002) Infectious tolerance: human CD25(+) regulatory $\mathrm{T}$ cells convey suppressor activity to conventional CD4(+) T helper cells. J Exp Med 196: 255-260.

69. Baecher-Allan C, Viglietta V, Hafler DA (2004) Human CD4+CD25+ regulatory T cells. Semin Immunol 16: 89-98.

70. Hartigan-O'Connor DJ, Poon C, Sinclair E, McCune JM (2007) Human CD4+ regulatory T cells express lower levels of the IL-7 receptor alpha chain (CD127), allowing consistent identification and sorting of live cells. J Immunol Methods 319: 41-52.

71. Liu W, Putnam AL, Xu-Yu Z, Szot GL, Lee MR, et al. (2006) CD127 expression inversely correlates with FoxP3 and suppressive function of human CD4+ T reg cells. J Exp Med 203: 1701-1711.

72. Gentleman RC, Carey VJ, Bates DM, Bolstad B, Dettling M, et al. (2004) Bioconductor: open software development for computational biology and bioinformatics. Genome Biol 5: R80.

73. Tusher VG, Tibshirani R, Chu G (2001) Significance analysis of microarrays applied to the ionizing radiation response. Proc Natl Acad Sci U S A 98: 5116-5121.

74. Baldi P, Long AD (2001) A Bayesian framework for the analysis of microarray expression data: regularized $\mathrm{t}$-test and statistical inferences of gene changes. Bioinformatics 17: 509-519.

75. Smyth GK (2004) Linear models and empirical bayes methods for assessing differential expression in microarray experiments. Stat Appl Genet Mol Biol 3: Article3.

76. Turro E, Bochkina N, Hein AM, Richardson S (2007) BGX: a Bioconductor package for the Bayesian integrated analysis of Affymetrix GeneChips. BMC Bioinformatics Under Review.

77. Hein AM, Richardson S, Causton HC, Ambler GK, Green PJ (2005) BGX: a fully Bayesian integrated approach to the analysis of Affymetrix GeneChip data. Biostatistics 6: 349-373.

78. Hein AM, Richardson S (2006) A powerful method for detecting differentially expressed genes from GeneChip arrays that does not require replicates. BMC Bioinformatics 7: 353 .

79. Efron B (2003) Large-scale simultaneous hypothesis testing: the choice of a null hypothesis. J Am Statist Assoc: 96: 99.

80. Ashburner M, Ball CA, Blake JA, Botstein D, Butler H, et al. (2000) Gene ontology: tool for the unification of biology. The Gene Ontology Consortium. Nat Genet 25: 25-29.

81. Glisic-Milosavljevic S, Waukau J, Jana S, Jailwala P, Rovensky J, et al. (2005) Comparison of apoptosis and mortality measurements in peripheral blood mononuclear cells (PBMCs) using multiple methods. Cell Prolif 38: 301-311. 